\title{
Microbial contamination and antimicrobial susceptibility pattern of bacterial isolates from sorghum and millet derived local beverage (Obushera) consumed in Mbarara City, Uganda
}

Amos Kiprotich ( $\nabla$ amozamos@gmail.com )

Mbarara University of Science and Technology

Rapheal Wangalwa

Mbarara University of Science and Technology

Jeninah Atwebembeire

Mbarara University of Science and Technology

Grace Kagoro-Rugunda

Mbarara University of Science and Technology

Research Article

Keywords:

Posted Date: March 8th, 2022

DOI: https://doi.org/10.21203/rs.3.rs-1419424/v1

License: (c) (1) This work is licensed under a Creative Commons Attribution 4.0 International License.

Read Full License 


\section{Abstract}

The high consumption and unconventional manner in which locally derived sorghum and millet beverages (Obushera) are processed in Uganda prompted the need to establish microbial safety of the beverages. Microbial contamination and its variation with storage time and temperature, antibioticsusceptibility of pathogenic bacterial isolates, and nutritional content of Obushera $(n=96)$ were determined. Handling and hygiene practices of processors and vendors of Obushera $(n=28)$ were also determined. Among the four categories of Obushera found in Mbarara city, Ekitiribita had the highest total viable counts (TVC) with a median of $4.62 \mathrm{log} \mathrm{CFU} / \mathrm{ml}$, followed by Obwenkiga and Obutiire with a median of 4.31 and $4.25 \mathrm{log} \mathrm{CFU} / \mathrm{ml}$, respectively. Microbial contaminants isolated included: Providencia spp.7(7.3\%), Coagulase-positive Staphylococci 23(24\%), Pseudomonas spp.3(3.1\%), Enterobacter cloacae 12 (12.5\%), Enterobacter aerogens 3 (3.1\%), Proteus vulgaris 15(15.6\%), Klebsiella spp. 13(13.5\%), Streptococcus spp. 7(7.3\%), and Escherichia coli 11 (11.5\%). Saccharomyces cerevisiae (65.6\%), Candida spp. (28.1\%), Mucorspp. and Aspergillus niger accounted for $52.1 \%$ contamination of all samples. The above microbial contaminants persisted with storage except Providencia spp., Proteus vulgaris, Mucor spp. and Aspergillus niger. Microbial and nutritional analyses showed a positive significant correlation between microbial counts and amino acid, carbohydrates, reducing sugar concentration and $\mathrm{pH}$ in Obushera ( $p$-value $<0.05)$. All isolated strains of bacteria were resistant to more than one family of antibiotics used. The review of hygiene and handling practices revealed that they did not conform to good manufacturing practices neither did they meet the East African Standards of $<2$ $\log _{10} \mathrm{CFU} / \mathrm{ml}$ TVC. Overall, this study revealed that Obushera consumed in Mbarara City, Uganda, is a high-risk beverage due to the high rate of microbial contamination and antibiotic resistance.

\subsection{Introduction}

The increase in global emergence and re-emergence of foodborne related pathogens have made the microbial quality of food a significant public health concern (Odeyemi \& Sani, 2016). Despite food's critical role in disease transmission, there is still a paucity of information related to foodborne diseases in developing nations, including Uganda (Grace, 2015). Consumption of food contaminated with pathogens and their resultant microbial by-products can lead to serious illnesses and economic losses (Ben et al., 2013). Presently, it is estimated that over 2 million deaths occurring in low and middle-income countries annually are attributable to foodborne diseases (Kelly et al., 2014). The most affected groups are the immunocompromised individuals because of their low immunity.

In Africa, more than 91 million people are affected by foodborne diseases (Organization, 2015). In Uganda, diarrheal diseases are among the top four causes of mortality and morbidity, especially in infants. In 2017, Uganda was ranked 27th globally, in diarrheal diseases' occurrence which accounted for 6.41 percent of deaths (Organization, 2014). The food implicated in foodborne illnesses included; fresh produce, food of animal origin, and street-vended food (Grace, 2015). Locally derived Sorghum/millet beverages, collectively known in the Runyakitara language spoken in Uganda as Obushera refer to a locally fermented or non-fermented non-alcoholic or alcoholic drinks, that are street-vended and 
consumed in western, southwestern, and central parts of Uganda. It is processed, commercially vended and served while cold under local brands namely Obwenkiga, Ekitiribita, Enturire, and Obutiire (Mukisa et al., 2012) .Obwenkiga is a sorghum-based Obushera prepared from malted sorghum and consumed within 1 or 2 days after production. Ekitiribita is a porridge prepared from un-malted millet and consumed between 1-2 days after processing (Mukisa et al., 2012). Enturire is an alcoholic type of Obushera that is prepared by fermenting malted sorghum for about 3 days to yield Obutoko and thereafter sweetening it with crude honey and fermenting it further for 2 to 4 days. Obutiire is a fermented millet-based local beverage produced by inoculating freshly made Ekitiribita with malted millet and fermenting it for 1-4 days (Mukisa et al., 2012). Among the four types of Obushera, Enturire, Obutiire, and Obwenkiga are fermented, while Ekitiribita is not fermented. Enturire is a known alcoholic type of Obushera but prolonged fermentation of Obwenkiga and Obutiire can yield alcoholic beverage.

Sorghum/ millet Obushera can be taken as refreshments or weaning food (Mukisa et al., 2012). The drink has been consumed in the local market and served in very village shops for a long time. However, the beverage is now becoming very popular among the urban population(Byakika et al., 2019). Due its increasing demand among Ugandans, particularly among urban dwellers, many entrepreneurs are now marketing the product commercially (Byakika et al., 2019). However, since fermented Obushera depends on chance fermentation, its quality and safety are not guaranteed.

Obushera is consumed ad libitum in urban, peri-urban, and rural areas in western and south-western parts of Uganda as a cheap alternative energy drink. The beverage is consumed in many households in Uganda as breakfast, during ceremonies such as weddings and funerals, and during field activities such as planting and harvesting. Also, there are claims among the rural population in Uganda that Obushera increases milk production in lactating mothers.

Even though Obushera is a nutritious drink with probiotic potential, its production in Uganda is still artisanal. Its processing is left with locals, hence making it hard to extend the shelf life and conserve the nutritional value of the beverage. The traditional methods of storing and drying sorghum and millet for Obushera and the eventual production procedure potentially expose the raw material to contamination by fungi, bacteria, and aflatoxins. Despite food safety gaps in processing and vending of Obushera and high consumption of the drink, especially in western and southwestern Uganda, limited research has been carried out on the microbial quality and safety of the beverage.

\subsection{Materials And Methods}

\subsection{Study area}

A cross-section study was carried out in three divisions of Mbarara City: Kakoba $\left(0.5980^{\circ} \mathrm{S}, 30.6791^{\circ} \mathrm{E}\right.$ GPS coordinates), Nyamitanga $\left(0.6167^{\circ} \mathrm{S}, 30.6333^{\circ} \mathrm{E}\right.$ GPS coordinates), and Kamukuzi $\left(0.60482^{\circ} \mathrm{S}\right.$, $30.63942^{\circ} \mathrm{E}$ GPS coordinates) located in western Uganda. Mbarara city is about 270 kilometers (168miles) by road southwest of Kampala, Uganda's capital, as shown in Fig. 1. 


\subsection{Study design}

A cross-sectional mixed approach was used in this study, whereby both qualitative design and quantitative study designs were used. The first phase of this design began by locating Enturire, Obutiire, Obwenkiga, and Ekitiribita processors and traders, then collecting samples of different types of the selected Obushera produced, and vended within Mbarara city. During this sample collection, a qualitative design through observation of the drink's handling was done with the help of pre-tested food handling compliance checklist. Contamination levels of the collected Obushera samples were determined with varied temperature and storage time using storage methods done by processors. Parameters such as $\mathrm{pH}$ and nutritional composition were determined to establish the influence of these parameters on levels of microbial contamination of Obushera. Finally, antimicrobial susceptibility of pathogenic bacterial isolates from collected sample against eight commonly used and essential antibiotics was determined.

\subsection{Sampling}

An integrated purposive and snowball sampling was used in this study. A purposive sampling technique was used to select the first few Obushera processors leading to other participants dealing with related Obushera by snowball sampling. The target population from different parts of Mbarara city dealing with different sorghum and millet drink varieties were nominated as multipliers. Samples of Obushera, including Enturire, Ekitiribita, Obutiire, and Obwenkiga, were picked from the selected Obushera processors and taken to the laboratory for microbial and nutritional analysis.

A total of 28 processors of both alcoholic and non-alcoholic sorghum and millet beverages (Obushera) were purposely selected within the populous divisions of Mbarara city. The 28 processors were observed for handling practices and hygiene during processing sites. The estimated population size of 28 was obtained using an online calculator (Raosoft, 2004) with a minimal error at $5 \%$, confidence level at $95 \%$. All the participants consented to participate in the study. An observation checklist adopted from Codex Alimentarius (Stankovic, 2015) with slight modification was used in collected data related to handling and hygiene practices of Obushera processors.

A total of 96 samples of locally derived sorghum and millet beverages (Obushera) comprising of 24 samples of each of; Enturire, Obwenkiga, Ekitiribita, and Obutiire, were collected from processors/vendors at three different divisions of; Kakoba, Nyamitanga, and Kamukuzi in Mbarara city, Uganda. The sample size for sorghum and millet Obushera was determined using the formula by Smith (2013) using 5\% microbial contamination on related street food by Gitahi (2012). Mbarara city was purposely selected because of its industrious nature and location in western parts of Uganda, where Obushera is traditionally produced and consumed in high quantities (Mukisa et al., 2012). From each of the Obushera categories namely Enturire, Ekitiribita, Obwenkiga, and Obutiire; random samples of 100 milliliter of samples were collected using sterile plastic universal bottles and transported in a cool box with ice blocks for microbial analysis at Mbarara Regional Referral Hospital's microbiology laboratory located within Mbarara university of science and technology. Samples were analyzed within 2-6 hours upon reaching the laboratory. 


\subsection{Determination of Microbial contaminants}

A total viable microbial plate count technique was used in enumerating total microbes present in sampled sorghum/millet beverages (Obushera). Briefly, the method involved 10-fold serial dilution of the samples and inoculation onto a suitable culture media. The homogenized sample was serially diluted by mixing one milliliter of the homogenized sample and 9 milliliters of a diluent buffer up to $10^{-5}$ using sterile universal bottles and transferred to culture media already prepared according to manufacturer's instructions (Collee et al., 1996). After vortexing, 1 millimeter of the suspension was aseptically transferred into sterile labeled Petri dishes, and sterile culture media was poured using the pour plate technique.

The total aerobic bacteria count was enumerated on plate count agar following standard bacteriology procedure ISO 4833 (de Normalisation, 2003). Before enumeration the plates for TVC were incubated for 24 hours at $37^{\circ} \mathrm{C}$. Significant microbial colonies between 25 and 300 were considered for total aerobic counts (TVC). All the plates were counted, and colony-forming units were calculated. The microbes' colony-forming units (CFU) per milliliter were obtained by using Miles and Misra method; $\mathrm{CFU} / \mathrm{ml}=$ (number of colonies $x$ dilution factor)/volume plates (Holt et al., 2013). On the other hand, the fungi were incubated at $25^{\circ} \mathrm{C}$ for 120 hours on Sabouraud Dextrose Agar (SDA) plates and total counts were enumerated following standards by (Masaphy, 2013) method. The SDA plates with 25-300 colonies of fungi were enumerated and expressed as colony-forming units. Presumptive bacterial identification was performed based on morphological features and gram reaction following standard bacteriological procedures (Holt et al., 2013). Pure colonies were obtained by sub-culturing presumptive bacteria into nutrient agar, blood agar, chocolate agar, mannitol salt agar and MacConkey agar and incubating them for further identification using biochemical tests and enzymatic reactions. Biochemical tests performed for gram-negative bacteria included Triple sugar iron agar (TSI), Urease test, Simmons citrate, and Sulfide Indole Motility (SIM) according to (Cowan, 1973). Gram-positive cocci were identified based on gram staining, catalase, and coagulase tests. Yeast growth and molds were differentiated based on their morphological properties and confirmed by microscopy. In identifying yeasts, gram staining and germ tube test was performed on colonies and examined microscopically. Molds were differentiated by using a lactophenol blue stain and examining its structure on a microscope. The variation of all the above Microbial contamination with storage was monitored every 24 hours for 14 days

\subsection{Nutritional analysis of Obushera with storage under different temperatures}

Variation in the selected nutritional composition of Obushera; amino acids, reducing sugars, carbohydrates and $\mathrm{pH}$ were determined every 24 hours over a 14-day storage under the processors storage temperature conditions of $4^{\circ} \mathrm{C}$ (refrigerated) and $26^{\circ} \mathrm{C}$ (ambient). The $\mathrm{pH}$ was determined using a table-top $\mathrm{pH}$ meter, while temperature variation was measured using a portable thermometer. Variation in time was measured using a digital timer stopwatch. Nutritional composition such as reducing sugars, carbohydrates, and amino acid concentration was done using the UV/VIS- spectrophotometric method. 
Amino-acid component of the drink was obtained using UV-spectrophotometric method (Nakai \& Le, 1970) with ninhydrin method of extraction, while carbohydrates were extracted and quantified using Sulphuric acid-UV method as described by (Albalasmeh et al., 2013). In the same way, reducing sugars were extracted using the Nelson-Somogyi method with modification according to (Green III et al., 1989) method.

\subsection{Antibiotic susceptibility testing (AST) of the pathogenic bacteria found in Obushera}

Antibiotic susceptibility profiles of isolated bacteria were determined using Mueller-Hinton Agar (MHA) (Oxoid, England) by Kirby-Bauer disk diffusing method following clinical and laboratory standard institute procedures (CLSI) (Wayne, 2010). Two to three single colonies were gently mixed with physiological saline water (0.85\% PBS) until the suspension was formed. The turbidity of the suspension was compared with the $0.5 \mathrm{McF}$ arland turbidity standard. The obtained bacterial suspension was then swabbed on MHA with a sterile cotton swab. Finally, antibiotic discs were applied within fifteen minutes with the help of sterile forceps and incubated at $37^{\circ} \mathrm{C}$ for a time of 24 hours. After 24 hours, the zone of inhibition of growth of bacteria around the discs was measured in millimeters using a ruler and interpreted according to CLSI. The bacteria Escherichia coli (ATCC 25922), Staphylococcus aureus (ATCC 25923) and Pseudomonas aeruginosa (ATCC 27853) were used as controls. The antibiotics used were: Ciprofloxacin $(5 \mu \mathrm{g})$, Penicillin $(10 \mu \mathrm{g})$, Amoxyclav $(30 \mu \mathrm{g})$, Cefuroxime $(30 \mu \mathrm{g})$, Erythromycin $(15 \mu \mathrm{g})$, Ceftriaxone $(30 \mu \mathrm{g})$, Tetracycline $(30 \mu \mathrm{g})$, and Ampicillin $(10 \mu \mathrm{g})$. These antibiotics represented essential and commonly used antibiotics for treating microbial infections in Uganda (Namugambe et al., 2021).

Multiple antibiotic resistance index (MAR) is an effective method used in tracking sources of antibiotic resistant bacteria (Ayandele et al., 2020). Multiple antibiotic resistance (MAR) indices were calculated as $\mathrm{a} /(\mathrm{bxc})$ whereby a represented the aggregate of all antibiotic resistance scores of all the bacteria, $\mathrm{b}$ represented the total number of antibiotics used, and $c$ was the number of the isolates. An MAR index of greater 0.2 indicates that the isolate was obtained from a high risk sources where antibiotics are often used.

\subsection{Data Analysis}

Microbial counts were transformed into logarithm of colony-forming units $\left(\log _{10} \mathrm{CFU} / \mathrm{ml}\right)$, entered in Excel, and analyzed on R studio and GraphPad Prism version 8. Descriptive statistics such as median, mean and standard deviation were computed. Analysis of variance was calculated to determine the difference in microbial contamination between or within the four different locally derived sorghum and millet beverages produced and consumed in Mbarara City, Uganda. The difference in means were computed using Tukey method at statistical difference at $p<0.05$. A Spearman's correlation was used to compute correlation between different parameters under study and correlation was achieved at a significance of $p<0.05$.

\subsection{Results And Discussions}




\subsection{Microbial Contamination levels of Obushera}

Based on the analysis of the four types of Obushera, Ekitiribita had the highest total viable bacterial counts (TVC) with a median of $4.62 \log 10 \mathrm{CFU} / \mathrm{ml}$, followed by Obwenkiga and Obutiire with a median of 4.31 and $4.25 \log 10 \mathrm{CFU} / \mathrm{ml}$, respectively as summarized in Fig. 2 . Therefore, these results indicate that consumers of Ekitiribita beverages are more at risk of foodborne infections because of higher exposure to potentially pathogenic bacteria from the beverage. The preparation techniques of Ekitiribita coupled with the fact that it is served when it is very cold, favor the proliferation of microbes revealed by this study. Similarly, Ekitiribita beverage is not fermented and has its $\mathrm{pH}$ towards neutrality, thus supporting the thriving of most microbes as revealed as revealed by this study. According to Muleta and Ashenafi (2001) holding food at low temperature for 4 to 6 hours increases the proliferation of microbial growth, which can pose a great risk to public health. Enturire had the least microbial counts with a TVC of $3.49 \log 10$ $\mathrm{CFU} / \mathrm{ml}$, which was expected considering that Enturire is a fermented type of Obushera sweetened with crude honey. Honey has been shown to possess antibacterial and antifungal activity, that inhibits the growth of microbes (Mandal \& Mandal, 2011).

The dominant bacteria isolated from the 96 Obushera samples (Table 1) were coagulase-positive Staphylococcus sp. (non-aureus) 23(24\%), followed by Proteus vulgaris 15(15.6\%), Klebsiella species 13(13.5\%), Enterobacter cloacae 12(12.5\%) and Escherichia coli11(11.5\%). Other bacteria isolated include Providencia spp. which was detected in 7 (7.3\%) of the samples, Pseudomonas spp. 3(3.1\%), Enterobacter aerogens 3 (3.1\%), and Streptococcus spp. 7(7.3\%). coagulase-positive Staphylococci (CoPS) is a commensal bacteria found in human skin and mucosal membranes. The CoPS can survive in all kinds of environments, and thus the bacteria could only have been transmitted to the beverages through cross-contamination from processors and vendors of Obushera to the drinks during the handling process and through the exposure of the beverage to an unhygienic environment. Other bacteria, including Proteus vulgaris, Escherichia coli and Enterobacter cloacae are normal gut flora and the possible route of transmission to Obushera is related to fecal nature from humans and vectors such as flies. Fecal contamination can occur from uncontrolled water from sewage getting in contact with beverages through the use of contaminated water. Processors and vendors could have also transferred the bacteria to beverage during handling especially for handlers who didn't wash their hands after visiting toilets. Klebsiella species of bacteria are often found in the environment and contamination of Obushera by this genera of bacteria were majorly due to unhygienic environment used by processors and vendors in preparing the beverages. Generally, our results indicate serious problem of Staphylococcus and coliforms contamination of Obushera consumed in Mbarara City, which agrees with the outcome of Byakika et al. (2019) who found similar results in sorghum and millet flour vended in Kampala market, Uganda. Overall, the occurrence of enteric bacteria such as Enterobacter cloacae, Enterobacter aerogenes, Klebsiella spp., E.coli, and Proteus vulgaris, and other isolated bacteria from Obushera is an indication of microbial contamination of the beverage from multiple sources such as handling, industrial wastes, and sewage effluents among others (Gufe et al., 2019). 
Table 1

Distribution of microbe and Percentage of culture-positive positive samples in Obushera sampled in Mbarara city, Uganda.

\begin{tabular}{|c|c|c|c|c|c|}
\hline Microbial group & $\begin{array}{l}\text { Number } \\
\text { of culture } \\
\text { positive } \\
\text { Enturire }\end{array}$ & $\begin{array}{l}\text { Number of } \\
\text { culture } \\
\text { positive } \\
\text { Ekitiribita }\end{array}$ & $\begin{array}{l}\text { Number of } \\
\text { culture } \\
\text { positive } \\
\text { Obwenkiga }\end{array}$ & $\begin{array}{l}\text { Number } \\
\text { of culture } \\
\text { positive } \\
\text { Obutiire }\end{array}$ & $\begin{array}{l}\text { Culture positive samples } \\
\text { as a percentage(\%) of } \\
\text { the Total samples ( } n= \\
96)\end{array}$ \\
\hline $\begin{array}{l}\text { Providencia } \\
\text { spp. }\end{array}$ & 7 & - & - & - & $7(7.3 \%)$ \\
\hline $\begin{array}{l}\text { Coagulase- } \\
\text { positive } \\
\text { Staphylococcus } \\
\text { sp. }\end{array}$ & 7 & 6 & 3 & 7 & $23(24 \%)$ \\
\hline $\begin{array}{l}\text { Proteus } \\
\text { vulgaris }\end{array}$ & - & - & 10 & 5 & $15(15.6 \%)$ \\
\hline $\begin{array}{l}\text { Streptococcus } \\
\text { spp. }\end{array}$ & - & 4 & - & 3 & $7(7.3 \%)$ \\
\hline Escherichia coli & - & 3 & 6 & 2 & 11 (11.5\%) \\
\hline Klebsiella spp. & - & 3 & 7 & 3 & $13(13.5 \%)$ \\
\hline $\begin{array}{l}\text { Pseudomonas } \\
\text { spp. }\end{array}$ & 3 & - & - & - & $3(3.1 \%)$ \\
\hline $\begin{array}{l}\text { Enterobacter } \\
\text { cloacae }\end{array}$ & 4 & 8 & - & - & $12(12.5 \%)$ \\
\hline $\begin{array}{l}\text { Enterobacter } \\
\text { aerogenes }\end{array}$ & - & 3 & - & - & $3(3.1 \%)$ \\
\hline $\begin{array}{l}\text { Saccharomyces } \\
\text { cerevisiae }\end{array}$ & 15 & 18 & 14 & 16 & $63(65.6 \%)$ \\
\hline Candida spp. & 4 & 5 & 10 & 8 & $27(28.1 \%)$ \\
\hline \multicolumn{6}{|l|}{$\begin{array}{l}\text { Aspergillus } \\
\text { niger }\end{array}$} \\
\hline - absence of orga & $m$ in the & age, ${ }^{*} \mathrm{cc}$ & rence of & me org & $\mathrm{n}$ in the beverage \\
\hline
\end{tabular}

Obutiire samples had the highest yeast counts with a median of $4.91 \log 10 \mathrm{CFU} / \mathrm{ml}$ (Fig. 2b), suggesting that Obutiire fermentation is dominated by yeast just like other cereal-based beverages (Vieira-Dalodé et al., 2007). The high yeast counts in Obutiire suggest that the drink is not suitable for consumers with yeast allergies and that the high consumption of the drink can cause oral candidiasis, due to high count of Candida species. A non-significant number of Molds were isolated from Enturire and Ekitiribita 
samples with a median of 0 (Fig. 2c). The low mold counts in Enturire could be due to the antifungal property of honey, as explained above, which could have inhibited the growth of molds in Enturire. Similarly, the low mold counts in Ekitiribita could be explained by the fact that the drink is prepared and consumed within a day when it is still fresh, hence, the short time between preparation and consumption does not allow for the growth of spoilage microbes such as molds.

In contrast, Obutiire samples had high molds counts with the median count of $1.54 \log _{10} \mathrm{CFU} / \mathrm{ml}$. The high mold counts in Obutiire is worrisome to consumers of the beverages, since molds, especially Aspergillus niger, which was isolated from the drink, can produce toxic mycotoxins such as aflatoxins, resulting in serious health threat to consumers of the beverage. Also Obwenkiga samples had a relatively high mold count with a median of $1.22 \log 10 \mathrm{CFU} / \mathrm{ml}$ (Fig. 2c). A high count of molds (both Mucorspp. and Aspergillus niger) in Obwenkiga and Obutiire types is attributable to raw materials used to process the beverages which are often germinated in a moist environment for some days, thus supporting the growth of molds. The mold spores are transferred directly from the raw materials to the drink during the preparation process, hence, the high mold counts revealed by our study. The outcome of microbial counts in this study differs from previous studies by (Mwambete \& Peter, 2011) who found a higher bacterial (4.1 $\left.\mathrm{x} 10^{5} \mathrm{CFU} / \mathrm{ml}\right)$ and fungal contamination $\left(6.4 \times 10^{6} \mathrm{CFU} / \mathrm{ml}\right)$ in non-alcoholic beverages in Tanzania. However, our findings corroborate those of (Elmahmood \& Doughari, 2007) who found microbial counts between $1.0 \times 10^{3}$ to $1.8 \times 10^{4}$ cells $/ \mathrm{ml}$ in Kunun-zaki drink; a fermented sorghum and millet drink consumed in West Africa.

The majority of fungi isolated were yeast and molds (Table 1), with yeast species being Saccharomyces cerevisiae and Candida species. Approximately 63 (65.6\%) of Obushera samples had Saccharomyces cerevisiae while 27 (28.1\%) of Obushera contained Candida species of yeast. Yeasts plays a major role in spoilage of the drink and are responsible for the production of off-flavors in Obushera. Consumption of Obushera with high yeast counts can lead to oral thrush caused by Candida species and allergies for consumers allergic to yeast. The higher percentage of Saccharomyces cerevisiae (65.6\%) in the samples indicates that the yeast participates actively in the fermentation of Obushera. About 50 (52.1\%) of Obushera sampled contained a mixture of Mucorspp. and Aspergillus nigertypes of molds.

Contamination of Obushera by Aspergillus niger is concerning since it can produce mycotoxins such as aflatoxins and ochratoxins; a threat to public health.

\subsection{Variation of Microbial contamination with storage time}

The results on variation in microbial contamination of Obushera with time under room temperature of $26^{\circ} \mathrm{C}$ and refrigerated temperature of $4^{\circ} \mathrm{C}$ are summarized in Table 2. Our findings observed a progressive decline in microbes over a storage duration of 14 days in both temperatures as also documented by Mendez-Vilas (2015) and Malav et al.(2013). The decline in microbial counts is possible since stored Obushera undergoes spontaneous fermentation, resulting in gradual acidification of the beverages. The gradual acidification of the drinks could facilitate the death of some microbes since the organic acid released as a result of fermentation inhibits microbes by lowering their intracellular pH (Raybaudi- 
Massilia et al., 2009). Low intracellular pH reduces the glycolysis process, cell signaling and causes inhibition of active transport (Raybaudi-Massilia et al., 2009). To maintain a balance, the microbes have to use adenosine triphosphate (ATP) to exclude excess protons, which depletes the energy required for growth and other energy-depended processes, thus leading to the death of the microbe (RaybaudiMassilia et al., 2009). Other microbes could have survived through the upregulation of specific proteins, which helps the microbe to adapt to an acidic environment (Byakika et al., 2019; Raybaudi-Massilia et al., 2009). There was no significant difference between mean contaminations of the drinks at room temperature and fridge temperature $(p>0.05)$, indicating that the microbes in Obusherasampled were both mesophilic and psychrophilic. 
Table 2

Variation in microbial contamination in Obushera over 14-day storage period

Days Total aerobic viable count expressed as $\log _{10}$ mean $\mathrm{cfu} / \mathrm{ml}$

\begin{tabular}{|c|c|c|c|c|c|c|c|c|}
\hline & \multicolumn{2}{|l|}{ Enturire } & \multicolumn{2}{|c|}{ Ekitiribita } & \multicolumn{2}{|c|}{ Obwenkiga } & \multicolumn{2}{|c|}{ Obutiire } \\
\hline & RM & FT & RM & $\mathrm{FT}$ & RM & $\mathrm{FT}$ & RM & $\mathrm{FT}$ \\
\hline 1 & $\begin{array}{l}4.68 \pm \\
0.11\end{array}$ & $\begin{array}{l}4.88 \pm \\
0.12\end{array}$ & $\begin{array}{l}5.13 \pm \\
0.11\end{array}$ & $\begin{array}{l}5.09 \pm \\
0.04\end{array}$ & $\begin{array}{l}5.66 \pm \\
0.32\end{array}$ & $\begin{array}{l}5.51 \pm \\
0.27\end{array}$ & $\begin{array}{l}5.48 \pm \\
0.43\end{array}$ & $\begin{array}{l}5.41 \pm \\
0.40\end{array}$ \\
\hline 2 & $\begin{array}{l}4.62 \pm \\
0.11\end{array}$ & $\begin{array}{l}4.79 \pm \\
0.15\end{array}$ & $\begin{array}{l}4.97 \pm \\
0.06\end{array}$ & $\begin{array}{l}5.09 \pm \\
0.06\end{array}$ & $\begin{array}{l}5.03 \pm \\
0.04\end{array}$ & $\begin{array}{l}5.10 \pm \\
0.06\end{array}$ & $\begin{array}{l}4.99 \pm \\
0.13\end{array}$ & $\begin{array}{l}5.09 \pm \\
0.02\end{array}$ \\
\hline 3 & $\begin{array}{l}3.75 \pm \\
0.18\end{array}$ & $\begin{array}{l}2.43 \pm \\
2.1\end{array}$ & $\begin{array}{l}4.13 \pm \\
0.08\end{array}$ & $\begin{array}{l}3.97 \pm \\
0.11\end{array}$ & $\begin{array}{l}4.31 \pm \\
0.37\end{array}$ & $\begin{array}{l}4.38 \pm \\
0.56\end{array}$ & $\begin{array}{l}4.10 \pm \\
0.05\end{array}$ & $\begin{array}{l}4.15 \pm \\
0.03\end{array}$ \\
\hline 4 & $3.5 \pm 0.2$ & $\begin{array}{l}3.7 \pm \\
0.15\end{array}$ & $\begin{array}{l}4.06 \pm \\
0.05\end{array}$ & $\begin{array}{l}4.11 \pm \\
0.04\end{array}$ & $\begin{array}{l}4.05 \pm \\
0.04\end{array}$ & $\begin{array}{l}4.08 \pm \\
0.03\end{array}$ & $\begin{array}{l}4.14 \pm \\
0.05\end{array}$ & $\begin{array}{l}4.12 \pm \\
0.03\end{array}$ \\
\hline 5 & $\begin{array}{l}3.29 \pm \\
0.11\end{array}$ & $\begin{array}{l}3.62 \pm \\
0.14\end{array}$ & $\begin{array}{l}3.89 \pm \\
0.06\end{array}$ & $\begin{array}{l}4.24 \pm \\
0.15\end{array}$ & $\begin{array}{l}4.08 \pm \\
0.02\end{array}$ & $\begin{array}{l}4.27 \pm \\
0.41\end{array}$ & $\begin{array}{l}4.16 \pm \\
0.02\end{array}$ & $\begin{array}{l}4.21 \pm \\
0.02\end{array}$ \\
\hline 6 & $\begin{array}{l}2.17 \pm \\
1.88\end{array}$ & $\begin{array}{l}2.2 \pm \\
1.93\end{array}$ & $\begin{array}{l}3.81 \pm \\
0.07\end{array}$ & $\begin{array}{l}3.92 \pm \\
0.06\end{array}$ & $\begin{array}{l}3.88 \pm \\
0.05\end{array}$ & $\begin{array}{l}3.96 \pm \\
0.06\end{array}$ & $\begin{array}{l}3.91 \pm \\
0.11\end{array}$ & $\begin{array}{l}3.98 \pm \\
0.12\end{array}$ \\
\hline 7 & $\begin{array}{l}2.3 \pm \\
0.52\end{array}$ & $\begin{array}{l}1.99 \pm \\
1.7\end{array}$ & $\begin{array}{l}3.61 \pm \\
0.02\end{array}$ & $\begin{array}{l}3.73 \pm \\
0.06\end{array}$ & $\begin{array}{l}3.72 \pm \\
0.05\end{array}$ & $\begin{array}{l}3.76 \pm \\
0.13\end{array}$ & $\begin{array}{l}3.75 \pm \\
0.04\end{array}$ & $\begin{array}{l}3.87 \pm \\
0.05\end{array}$ \\
\hline 8 & $\begin{array}{l}2.72 \pm \\
0.06\end{array}$ & $\begin{array}{l}2.62 \pm \\
0.12\end{array}$ & $\begin{array}{l}3.61 \pm \\
0.11\end{array}$ & $\begin{array}{l}3.68 \pm \\
0.09\end{array}$ & $\begin{array}{l}3.56 \pm \\
0.08\end{array}$ & $\begin{array}{l}3.69 \pm \\
0.16\end{array}$ & $\begin{array}{l}3.60 \pm \\
0.04\end{array}$ & $\begin{array}{l}3.62 \pm \\
0.06\end{array}$ \\
\hline 9 & $\begin{array}{l}2.49 \pm \\
0.13\end{array}$ & $\begin{array}{l}2.06 \pm \\
0.79\end{array}$ & $\begin{array}{l}3.10 \pm \\
0.05\end{array}$ & $\begin{array}{l}3.12 \pm \\
0.05\end{array}$ & $\begin{array}{l}3.16 \pm \\
0.04\end{array}$ & $\begin{array}{l}3.18 \pm \\
0.03\end{array}$ & $\begin{array}{l}3.13 \pm \\
0.04\end{array}$ & $\begin{array}{l}3.17 \pm \\
0.04\end{array}$ \\
\hline 10 & $\begin{array}{l}2.32 \pm \\
0.09\end{array}$ & $\begin{array}{l}2.49 \pm \\
0.06\end{array}$ & $\begin{array}{l}2.95 \pm \\
0.05\end{array}$ & $\begin{array}{l}3.02 \pm \\
0.02\end{array}$ & $\begin{array}{l}2.96 \pm \\
0.09\end{array}$ & $\begin{array}{l}3.04 \pm \\
0.04\end{array}$ & $\begin{array}{l}3.03 \pm \\
0.04\end{array}$ & $\begin{array}{l}3.04 \pm \\
0.06\end{array}$ \\
\hline 11 & $\begin{array}{l}2.15 \pm \\
0.13\end{array}$ & $\begin{array}{l}2.47 \pm \\
0.09\end{array}$ & $\begin{array}{l}2.79 \pm \\
0.10\end{array}$ & $\begin{array}{l}2.71 \pm \\
0.29\end{array}$ & $\begin{array}{l}2.81 \pm \\
0.03\end{array}$ & $\begin{array}{l}2.88 \pm \\
0.03\end{array}$ & $\begin{array}{l}2.85 \pm \\
0.10\end{array}$ & $\begin{array}{l}2.90 \pm \\
0.08\end{array}$ \\
\hline 12 & $\begin{array}{l}1.94 \pm \\
0.15\end{array}$ & $\begin{array}{l}2.16 \pm \\
0.09\end{array}$ & $\begin{array}{l}2.57 \pm \\
0.09\end{array}$ & $\begin{array}{l}2.67 \pm \\
0.05\end{array}$ & $\begin{array}{l}2.56 \pm \\
0.09\end{array}$ & $\begin{array}{l}2.64 \pm \\
0.22\end{array}$ & $\begin{array}{l}2.65 \pm \\
0.09\end{array}$ & $\begin{array}{l}2.67 \pm \\
0.14\end{array}$ \\
\hline 13 & $\begin{array}{l}1.75 \pm \\
0.08\end{array}$ & $\begin{array}{l}1.87 \pm \\
0.18\end{array}$ & $\begin{array}{l}2.03 \pm \\
0.02\end{array}$ & $\begin{array}{l}1.97 \pm \\
0.08\end{array}$ & $\begin{array}{l}2.02 \pm \\
0.03\end{array}$ & $\begin{array}{l}1.93 \pm \\
0.17\end{array}$ & $\begin{array}{l}2.06 \pm \\
0.04\end{array}$ & $\begin{array}{l}2.13 \pm \\
0.05\end{array}$ \\
\hline 14 & $\begin{array}{l}1.57 \pm \\
0.08\end{array}$ & $\begin{array}{l}1.49 \pm \\
0.1\end{array}$ & $\begin{array}{l}1.93 \pm \\
0.06\end{array}$ & $\begin{array}{l}1.98 \pm \\
0.07\end{array}$ & $\begin{array}{l}1.90 \pm \\
0.07\end{array}$ & $\begin{array}{l}1.85 \pm \\
0.12\end{array}$ & $\begin{array}{l}1.92 \pm \\
0.03\end{array}$ & $\begin{array}{l}1.93 \pm \\
0.04\end{array}$ \\
\hline
\end{tabular}




\subsection{Variation in contamination levels with storage conditions of Obushera}

Proteus vulgaris persisted with storage of Obushera for 3 and 4 days while under room and refrigerated temperature $\left(4^{\circ} \mathrm{C}\right)$ as shown in Fig. 3. Proteus vulgaris and other gram-negative bacteria have a thin peptidoglycan layer (murein) which does not well protect against any physical stress such as acid stress; hence they need a higher humidity and low temperature to survive longer. Similarly, the short persisted of Proteus vulgaris is related to its low initial inoculum size of $3.98 \mathrm{log} \mathrm{CFU} / \mathrm{ml}$ compared to other isolated gram-negative bacteria such as Klebsiella spp. with inoculum size of $4.9 \mathrm{log} \mathrm{CFU} / \mathrm{ml}$. Inoculum size affects the persistence of microbes with microbes with a higher initial inoculum size showing a longer persistence time in beverages. Pseudomonas and Providencia spp. survived for 4 and 3 days respectively (Fig. 3) because of their thin peptidoglycan layer which cannot protect them for a longer time against physical stress such as fluctuating $\mathrm{pH}$ as observed in Obushera. Also, Pseudomonas and Providencia spp. had a smaller inoculum sizes of $3.61 \mathrm{log} \mathrm{CFU} / \mathrm{ml}$ and $3.53 \mathrm{log} \mathrm{CFU} / \mathrm{ml}$ respectively, hence, their low inoculum sizes affected persistence of these two microbes in Obushera. Kramer et al.(2006) and Mitscherlich and Marth (2012) also found survival of Proteus vulgaris to be between 1 and 2 days. Neely (2000) also reported that Providencia spp. and Pseudomonas spp. could survive for 2 days.

Results from this study showed that coagulase-positive Staphylococci (CoPS) bacteria persisted for the entire storage time of 14 days of Obushera, but diminished faster under room temperature conditions compared to refrigerated temperature conditions $\left(4^{\circ} \mathrm{C}\right)$. These Gram-positive bacteria such as CoPS have thick peptidoglycan (murein) layer that greatly protects them against physical stress such as $\mathrm{pH}$ and temperature stress. The high inoculum size of $4.81 \mathrm{log} \mathrm{CFU} / \mathrm{ml}$ could have also helped CoPS to persist for the entire storage time. However, the inoculum size diminished faster at ambient temperature because the microbes increase exponentially at this temperature, depleting nutrients faster, and consequentially accumulating toxic wastes such as organic acids from the breakdown of nutrients. The unfavorable conditions characterized by competition for declining nutrients at room temperature $\left(26^{\circ} \mathrm{C}\right)$ cause a progressive decline in microbial counts with storage time. The majority of microbes, including CoPS produces virulence factors to cope with the harsh condition; therefore, consumption of Obushera with such bacteria can easily cause diseases to consumers. Under refrigerated temperature $\left(4^{\circ} \mathrm{C}\right)$, the activity of microbes such as CoPS are low, hence the rate of nutrient use is low and the result wastes accumulation is at a slow rate, thus, the decline in microbial counts is low, as revealed by our study. Wagenvoort et al.(2000) also observed a prolonged survival of methicillin-resistant Staphylococcus aureus (MRSA), but with a gradual decline in survival rate over a more extended storage period of food. Escherichia coli persisted for the entire 14-day storage time of Obushera, albeit with a decline in counts, majorly due to its high initial inoculum size of $5.0 \mathrm{log} \mathrm{CFU} / \mathrm{ml}$, the death microbes could have likely provided nutrients for other microbes, thus enabling them to survive for the entire storage period.

The increased competition for declining nutrients, and low pH explains the declining bacterial cell counts of Klebsiella spp., however, its persistence over the entire 14-day storage time is attributable to its high 
inoculum size of $4.9 \log \mathrm{CFU} / \mathrm{ml}$. There was a rapid decline in inoculum size of Klebsiella spp. at $26^{\circ} \mathrm{C}$ compared to $4^{\circ} \mathrm{C}$ because of high metabolic activity of the bacteria at ambient temperature which results in faster decline in nutrients as compared to refrigerated temperature $\left(4^{\circ} \mathrm{C}\right)$. The bacteria Enterobacter cloacae and Enterobacter aerogenes shared a similar persistence pattern in Obushera over a 14-day storage time.

The mold species, including Mucorspp. and Aspergillus niger persisted for an average time of 6 and 8 days (Fig. 3), respectively, under ambient temperature and an extra day under refrigeration and this could be attributed to the drop in $\mathrm{pH}$ on the 8th day of storage of Obushera which could have inhibited the growth of molds in Obushera under both temperature conditions. Declining nutrients and competition for limited nutrients with bacteria may have inhibited growth of molds. At the same time, the bacteria in response of stress may have produce antimicrobials such as cephalosporin which retards growth of molds. Nevertheless, under stress conditions such as declining nutrients and low $\mathrm{pH}$, molds such as Aspergillus niger are able to release spores and mycotoxins including aflatoxins, hence, consumers of Obushera who consumers Obushera stored for longer duration are at risk of aflatoxin exposure compared to those who consume fresh Obushera. Richardson and Rautemaa-Richardson (2020) explained that most molds, including Mucorspp. and Aspergillus niger, have their $\mathrm{pH}$ towards neutrality; hence, any changes in pH could have a detrimental effect on the growth of molds. The persistence of Candida spp. and Saccharomyces cerevisiae is majorly attributable to its ability to form extracellular matrix that helps it cope with changing environmental conditions and nutrients shortage. The refrigeration temperature $\left(4^{\circ} \mathrm{C}\right)$ increased survival rates of yeasts because at cooler temperature there is reduced competition with other microbes and abundant nutrients, but the progressive decline is due to a slow but steady decline in nutrients and low $\mathrm{pH}$. It was observed that low temperature and, in particular, refrigeration temperature of $4^{\circ} \mathrm{C}$ increases survival of bacteria and fungi in already contaminated beverages especially psychrotrophic and mesophilic microbes.

\subsection{Effect of $\mathrm{pH}$ and nutritional composition on microbial contamination}

The relationship of selected nutrients and $\mathrm{pH}$ on microbial contamination under both room and fridge temperature are as shown in Table 3. The findings revealed a significant positive correlation between $\mathrm{pH}$ $(p=0.04)$, and amino-acid concentration $(p=0.02)$ with microbial contamination in Enturire at room temperature and its reducing sugars $(p=0.04)$ with microbial contamination at refrigeration temperature $\left(4^{\circ} \mathrm{C}\right)$. Reducing sugars $(\mathrm{p}=0.0006)$, amino acids $(\mathrm{p}=0.0), \mathrm{pH}(\mathrm{p}=0.003)$ in Ekitiribita at $26^{\circ} \mathrm{C}$, and $\mathrm{pH}(\mathrm{p}$ $=0.001)$ at $4^{\circ} \mathrm{C}$ were positively correlated with microbial contamination. Reducing sugars $(p=0.02)$, amino acids $(p=0.00)$, and $\mathrm{pH}(\mathrm{p}=0.004)$ in Obutiire at room temperature, amino acids $(\mathrm{p}=0.004), \mathrm{pH}$ $(0.00)$ at $4^{\circ} \mathrm{C}$ were significantly positively correlated with its microbial contamination while Carbohydrate $(p=0.03)$, amino acids $(p=0.00)$, reducing sugars $(p=0.001)$, and $\mathrm{pH}(\mathrm{p}=0.00)$ at room temperature $\left(26^{\circ} \mathrm{C}\right), \mathrm{pH}(\mathrm{p}=0.0007)$, reducing sugar $(p=0.04)$ at refrigeration $\left(4^{\circ} \mathrm{C}\right)$ temperature were reported to have a significant positive effect on microbial contamination of Obwenkiga drink. Foodborne microbes derive 
their energy sources from carbohydrates, amino acids, and alcohols as reveled by our findings which agrees with Jay (Jay, 2000) and the US Food and Drug Administration (Administration, 2013) that microorganisms utilize macro-nutrients as the primary sources of energy. 
Table 3

Relationship between selected macro-nutrients (carbohydrates, reducing sugars, amino-acids), pH and microbial contamination (TVC) of Obushera

Enturire at Room Temperature $\left(26^{\circ} \mathrm{C}\right)$

Variables

(1)TVC

(2)Carbohydrates

(3) Reducing

sugars
(4)Amino Acids
0.62
$0.86^{*} \quad 0.56^{*} \quad 1$
$0.54^{\star} \quad 0.94^{\star}$
$0.79 * \quad 1$
(5) $\mathrm{pH}$
$0.56^{*}$
0.29
$-0.04$
$0.56^{\star}$

Ekitiribita at Room Temperature

$\begin{array}{lll}\text { (1)TVC } & 1 & 1\end{array}$

(2)Carbohydrates

$0.16 \quad 1$

$-0.2 \quad 1$

(3)Reducing

$0.82 * \quad 0.3 \quad 1$

$\begin{array}{lll}-0.002 & 0.5^{\star} & 1\end{array}$

sugars
(4)Amino Acids
0.99* $0.08 \quad 0.85 * 1$
0.09
0.1
$-0.04 \quad 1$

(5) $\mathrm{pH}$

$\begin{array}{lll}0.73 * & -0.19 & 0.49\end{array}$

$0.71 \quad 1$

$0.77 *$

$-0.48$

$-0.32$

0.1

Obwenkiga at Fridge Temperature

Obwenkiga at Room Temperature

$\begin{array}{lll}(1) T V C & 1 & 1\end{array}$

$\begin{array}{lllll}\text { (2) Carbohydrates } & 0.58^{*} & 1 & 0.07 & 1\end{array}$
(3)Reducing
$0.79 * 0.82 * 1$
$0.56^{*}$
$0.75^{\star} \quad 1$

sugars
(4)Amino Acids
0.96 *
$0.7 *$
$0.85^{\star} \quad 1$
0.45
$0.84^{\star} \quad 0.82^{\star} \quad 1$
(5) $\mathrm{pH}$
$0.79 * \quad 0.35$
$0.55^{*}$
$0.75^{\star} \quad 1$
$0.79 *$
$-0.06$
0.33
$0.22 \quad 1$

Obutiire at Room Temperature

Obutiire at Fridge Temperature
(1)TVC
1
1
(2) Carbohydrates
$0.1 \quad 1$
$0.07 \quad 1$
(3)Reducing
$0.61^{\star} \quad 0.61$
1
$0.54 *$
$0.77 * \quad 1$
sugars
(4)Amino Acids
0.96 *
0.11
$0.48 \quad 1$
$0.72 *$
0.57 *
$0.68^{*} \quad 1$

* significant correlation at $p<0.05$ 

(5) $\mathrm{pH}^{\top}$
$0.72 *$
$-0.3$
0.19
$0.74^{*}$
$1 \quad 0.87 *$
$-0.1$
0.39
$0.53^{*}$

* significant correlation at $p<0.05$

\subsection{Antimicrobial susceptibility patterns of the isolated bacteria}

Most of the coagulase-positive Staphylococcus sp. (CoPs) isolated showed less sensitivity to most antibiotics tested, with only five (33.3\%) showing sensitivity to ciprofloxacin (Table 4). The sensitivity of CoPs to tetracycline and ceftriaxone was $(2 / 13.3 \%)$, while $(1 / 6.7 \%)$ was sensitive to amoxiclav. None of the seven isolated Streptococcus spp. was susceptible to any antibiotics tested. Five (100\%) Enterobacter aerogens isolated in this study were sensitive to only ciprofloxacin, and none were sensitive to the remaining antibiotics. Regarding sensitivity of Providencia species, six (6/75\%) were susceptible to amoxiclav, while four (50\%) were sensitive to ceftriaxone and tetracycline. Only three (33.3\%) isolates of Enterobacter cloacae were susceptible to amoxyclav and ceftriaxone.

The sensitivity pattern of Klebsiella spp., as shown in Table 4, shows that Klebsiella species from Obushera were susceptible to ciprofloxacin and ceftriaxone, with most isolates (8/88.9\%) being susceptible to the antibiotics. Also, most Klebsiella spp. (7/ 77.8\%) were susceptible to cefuroxime, but low sensitivity was observed in the remaining antimicrobials. The majority of $E$. coli (8/80\%) were susceptible to ciprofloxacin and ceftriaxone, while six (6/60\%) were sensitive to cefuroxime. Proteus vulgaris showed high sensitivity to ciprofloxacin and ceftriaxone, in which eight isolates (66.7\%) were sensitive to the two antibiotics. All Pseudomonas species (6/100\%) were not sensitive to any antibiotics tested. Our study shows that most bacterial isolates were susceptible to ciprofloxacin, ceftriaxone and cefuroxime, suggesting that these drugs are still effective against foodborne bacteria in Mbarara city, Uganda. In summary, the isolated bacteria showed high susceptibility to cefuroxime, ceftriaxone and ciprofloxacin drugs. This implies that the three antibiotics are rarely used in Mbarara city. The high sensitivity of bacteria to ciprofloxacin has been reported in other studies (Ali et al., 2010; Barrett et al., 1999; Goswami et al., 2011). In general, the high bacterial resistance isolated from this study to penicillin, ampicillin, erythromycin, tetracycline, and amoxyclav antibiotics could be due to indiscriminate use of these antibiotics in Mbarara city in particular of sub-therapeutic doses resulting in bacterial drug tolerance. The multi-drug resistance to essential antibiotics such as penicillin, ampicillin, erythromycin, tetracycline and amoxyvlav is alarming since these antibiotics are often used to treat microbial infection in the community (Akindele et al., 2010). Tetracycline is the first-line drug and most available antibiotic for treating livestock; hence, some bacteria could have obtained their resistance through environmental exposure from animal waste from the environment and humans through contamination of the beverages. Therefore, one health approach should be adopted for the management of antibiotic resistance in 
Mbarara city. High resistance pattern to tetracycline has been reported in previous studies by Olatoye (2010) in Nigeria, Alhaj et al.(2007) in Malaysia while Shitandi and Sternesjö (2001) observed high bacterial resistance to penicillin and tetracycline in Kenya. 
Table 4

Antibiotic susceptibility profiles of bacteria isolated from sorghum and millet local beverage (Obushera) in Mbarara City, Uganda

\begin{tabular}{|c|c|c|c|c|c|c|c|c|c|}
\hline \multirow[t]{2}{*}{ Bacterial Isolates } & \multirow[t]{2}{*}{ Sensitivity } & \multicolumn{8}{|c|}{ Antibiotic's sensitivity (\%) } \\
\hline & & CIP & $P$ & AMC & CXM & CRO & TE & AMP & $E$ \\
\hline \multirow{3}{*}{$\begin{array}{l}\text { Staphylococcussp. } \\
\text { (coagulase-positive, } \\
\text { non-aureus) }\end{array}$} & $\mathrm{R}$ & $60(9)$ & $\begin{array}{l}100 \\
(15)\end{array}$ & $\begin{array}{l}66.7 \\
(10)\end{array}$ & $\begin{array}{l}80 \\
(12)\end{array}$ & $\begin{array}{l}66.7 \\
(10)\end{array}$ & $\begin{array}{l}86.7 \\
(13)\end{array}$ & - & $\begin{array}{l}100 \\
(15)\end{array}$ \\
\hline & I & $\begin{array}{l}6.7 \\
(1)\end{array}$ & 0 & $\begin{array}{l}26.7 \\
(4)\end{array}$ & $\begin{array}{l}20 \\
(3)\end{array}$ & $\begin{array}{l}20 \\
(3)\end{array}$ & 0 & - & 0 \\
\hline & $S$ & $\begin{array}{l}33.3 \\
\text { (5) }\end{array}$ & 0 & $\begin{array}{l}6.7 \\
(1)\end{array}$ & 0 & $\begin{array}{l}13.3 \\
\text { (2) }\end{array}$ & $\begin{array}{l}13.3 \\
\text { (2) }\end{array}$ & - & 0 \\
\hline \multirow[t]{3}{*}{ Streptococcus spp. } & $\mathrm{R}$ & $\begin{array}{l}100 \\
(7)\end{array}$ & $100(7)$ & - & $\begin{array}{l}100 \\
(7)\end{array}$ & $\begin{array}{l}100 \\
(7)\end{array}$ & $\begin{array}{l}100 \\
(7)\end{array}$ & $\begin{array}{l}100 \\
(7)\end{array}$ & $\begin{array}{l}100 \\
(7)\end{array}$ \\
\hline & 1 & 0 & 0 & - & 0 & 0 & 0 & 0 & 0 \\
\hline & $S$ & 0 & 0 & - & 0 & 0 & 0 & 0 & 0 \\
\hline \multirow[t]{3}{*}{ E. aerogenes } & $\mathrm{R}$ & 0 & - & - & $\begin{array}{l}100 \\
(5)\end{array}$ & 0 & $\begin{array}{l}100 \\
\text { (5) }\end{array}$ & $\begin{array}{l}100 \\
\text { (5) }\end{array}$ & - \\
\hline & I & 0 & - & - & 0 & $\begin{array}{l}100 \\
\text { (5) }\end{array}$ & 0 & 0 & - \\
\hline & $S$ & $\begin{array}{l}100 \\
(5)\end{array}$ & - & - & 0 & 0 & 0 & 0 & - \\
\hline \multirow[t]{3}{*}{ Providencia spp. } & $\mathrm{R}$ & $\begin{array}{l}25 \\
(2)\end{array}$ & - & 0 & $\begin{array}{l}75 \\
(6)\end{array}$ & $\begin{array}{l}50 \\
(4)\end{array}$ & $\begin{array}{l}50 \\
(4)\end{array}$ & $\begin{array}{l}100 \\
\text { (8) }\end{array}$ & - \\
\hline & I & $\begin{array}{l}50 \\
(4)\end{array}$ & - & $\begin{array}{l}25 \\
(2)\end{array}$ & 0 & 0 & 0 & 0 & - \\
\hline & $S$ & $\begin{array}{l}25 \\
(2)\end{array}$ & - & $\begin{array}{l}75 \\
(6)\end{array}$ & $\begin{array}{l}25 \\
(2)\end{array}$ & $\begin{array}{l}50 \\
(4)\end{array}$ & $\begin{array}{l}50 \\
(4)\end{array}$ & 0 & - \\
\hline \multirow[t]{3}{*}{ E.cloacae } & $\mathrm{R}$ & $\begin{array}{l}66.7 \\
(6)\end{array}$ & $\begin{array}{l}100 \\
(9)\end{array}$ & $\begin{array}{l}100 \\
\text { (9) }\end{array}$ & $\begin{array}{l}55.6 \\
(5)\end{array}$ & $\begin{array}{l}66.7 \\
(6)\end{array}$ & $\begin{array}{l}100 \\
\text { (9) }\end{array}$ & $\begin{array}{l}100 \\
\text { (9) }\end{array}$ & $\begin{array}{l}100 \\
(9)\end{array}$ \\
\hline & 1 & $\begin{array}{l}33.3 \\
\text { (3) }\end{array}$ & 0 & 0 & $\begin{array}{l}11.1 \\
(1)\end{array}$ & 0 & 0 & 0 & 0 \\
\hline & $S$ & 0 & 0 & 0 & $\begin{array}{l}33.3 \\
(3)\end{array}$ & $\begin{array}{l}33.3 \\
\text { (3) }\end{array}$ & 0 & 0 & 0 \\
\hline Klebsiella spp. & $\mathrm{R}$ & 0 & - & $\begin{array}{l}66.7 \\
(6)\end{array}$ & $\begin{array}{l}11.1 \\
(1)\end{array}$ & $\begin{array}{l}11.1 \\
\text { (1) }\end{array}$ & $\begin{array}{l}33.3 \\
\text { (3) }\end{array}$ & $\begin{array}{l}100 \\
(9)\end{array}$ & - \\
\hline
\end{tabular}

In parenthesis () represents the number of bacteria isolated, $\mathrm{R}=$ resistant isolate, $\mathrm{I}=$ Intermediate, $\mathrm{S}=$ Susceptible, $\mathrm{CIP}=$ Ciprofloxacin, $\mathrm{P}=$ Penicillin, $\mathrm{AMC}=$ Amoxyclav, $\mathrm{CXM}=$ Cefuroxime, $\mathrm{CRO}=$ Cefriaxone, $\mathrm{TE}=$ Tetracycline, $\mathrm{AMP}=$ Ampicillin, $\mathrm{E}=$ Erythromycin, - susceptibility test was not performed 


\begin{tabular}{|c|c|c|c|c|c|c|c|c|c|}
\hline & I & $\begin{array}{l}11.1 \\
(1)\end{array}$ & - & $\begin{array}{l}22.2 \\
(2)\end{array}$ & $\begin{array}{l}11.1 \\
(1)\end{array}$ & 0 & $\begin{array}{l}33.3 \\
\text { (3) }\end{array}$ & 0 & - \\
\hline & $S$ & $\begin{array}{l}88.9 \\
(8)\end{array}$ & - & $\begin{array}{l}11.1 \\
(1)\end{array}$ & $\begin{array}{l}77.8 \\
(7)\end{array}$ & $\begin{array}{l}88.9 \\
(8)\end{array}$ & $\begin{array}{l}33.3 \\
\text { (3) }\end{array}$ & 0 & - \\
\hline \multirow[t]{3}{*}{ E.coli } & $\mathrm{R}$ & $\begin{array}{l}20 \\
(2)\end{array}$ & - & $\begin{array}{l}80 \\
(8)\end{array}$ & $\begin{array}{l}30 \\
(3)\end{array}$ & $\begin{array}{l}20 \\
(2)\end{array}$ & $\begin{array}{l}70 \\
(7)\end{array}$ & $\begin{array}{l}70 \\
(7)\end{array}$ & - \\
\hline & I & 0 & - & 0 & $\begin{array}{l}10 \\
(1)\end{array}$ & 0 & $\begin{array}{l}20 \\
(2)\end{array}$ & $\begin{array}{l}30 \\
(3)\end{array}$ & - \\
\hline & $S$ & $\begin{array}{l}80 \\
(8)\end{array}$ & - & $\begin{array}{l}20 \\
(2)\end{array}$ & $\begin{array}{l}60 \\
(6)\end{array}$ & $\begin{array}{l}80 \\
(8)\end{array}$ & $\begin{array}{l}10 \\
(1)\end{array}$ & 0 & - \\
\hline \multirow[t]{3}{*}{ Proteus vulgaris } & $\mathrm{R}$ & $\begin{array}{l}33.3 \\
(4)\end{array}$ & - & $\begin{array}{l}91.7 \\
(11)\end{array}$ & $\begin{array}{l}58.3 \\
(7)\end{array}$ & $\begin{array}{l}33.3 \\
(4)\end{array}$ & $\begin{array}{l}100 \\
(12)\end{array}$ & $\begin{array}{l}91.7 \\
(9)\end{array}$ & - \\
\hline & I & 0 & - & 0 & $\begin{array}{l}25 \\
(3)\end{array}$ & 0 & 0 & 0 & - \\
\hline & $S$ & $\begin{array}{l}66.7 \\
(8)\end{array}$ & - & $\begin{array}{l}8.3 \\
(1)\end{array}$ & $\begin{array}{l}16.7 \\
(2)\end{array}$ & $\begin{array}{l}66.7 \\
(8)\end{array}$ & 0 & $\begin{array}{l}8.3 \\
(1)\end{array}$ & - \\
\hline \multirow[t]{3}{*}{ Pseudomonas spp. } & $\mathrm{R}$ & $\begin{array}{l}100 \\
(6)\end{array}$ & $\begin{array}{l}100 \\
(6)\end{array}$ & $\begin{array}{l}100 \\
(6)\end{array}$ & $\begin{array}{l}50 \\
(3)\end{array}$ & $\begin{array}{l}100 \\
(6)\end{array}$ & $\begin{array}{l}100 \\
(6)\end{array}$ & $\begin{array}{l}100 \\
(6)\end{array}$ & $\begin{array}{l}100 \\
\text { (6) }\end{array}$ \\
\hline & I & 0 & 0 & 0 & $\begin{array}{l}50 \\
(3)\end{array}$ & 0 & 0 & 0 & 0 \\
\hline & $S$ & 0 & 0 & 0 & 0 & 0 & 0 & 0 & 0 \\
\hline \multicolumn{10}{|c|}{$\begin{array}{l}\text { In parenthesis }() \text { represents the number of bacteria isolated, } R=\text { resistant isolate, } I=\text { Intermediate, } S= \\
\text { Susceptible, CIP = Ciprofloxacin, } P=P \text { Penicillin, } A M C=A m o x y c l a v, C X M=C \text { Cefuroxime, } C R O= \\
\text { Cefriaxone, } T E=\text { Tetracycline, AMP = Ampicillin, } E=\text { Erythromycin, - susceptibility test was not } \\
\text { performed }\end{array}$} \\
\hline
\end{tabular}

Multiple antibiotic resistance (MAR) was observed in all bacterial isolates from sampled Obushera (Table 5). The calculated MAR index of bacteria ranged from 0.22 to 1 , with the most frequent MAR being 1 in Streptococcus species and Proteus vulgaris isolates. The two most resistant isolates; Streptococcus spp. and Proteus vulgaris were found in Obutiire (2) and Ekitiribita (1) types of Obushera. This could suggest that two types of locally processed sorghum and millet beverages were obtained from high-risk sites which are Kakoba, Kamukuzi and Nyamitanga divisions of Mbarara city, where antibiotics were commonly used. The spread of these highly resistant bacteria clones can have severe public health consequences (Le Hello et al., 2011). The public health consequence of spreading of resistant strains of Streptococcus spp. and Proteus spp. is that it may colonize human population causing hard to treat infections. Further, Mishra et al.(2013) and Thenmozhi et al.(2014) explained that the MAR index of 0.2 and above shows that the isolates are from high-risk contaminated sources where antibiotics are commonly used. In the current study, all bacterial isolates had a MAR index of more than 0.2 , and this is alarming; thus, treatment regimens of patients with bacterial infections in Mbarara city, Uganda, must be guided by laboratory investigation. 
Table 5

Multiple antibiotic resistance (MAR) indices of all bacterial isolates from" Obushera" in Mbarara City, Uganda.

\begin{tabular}{|c|c|c|c|c|}
\hline Bacterial species & Enturire & Ekitiribita & Obwenkiga & Obutiire \\
\hline Staphylococcus sp. & $32(0.92)$ & $14(0.67)$ & $11(0.79)$ & $30(0.86)$ \\
\hline Enterobacter cloacae & $7(0.58)$ & $26(0.72)$ & - & - \\
\hline Providencia spp. & $12(0.5)$ & - & - & - \\
\hline Pseudomonas spp. & $15(0.94)$ & - & - & - \\
\hline Streptococcus spp. & - & $16(1)$ & - & $16(1)$ \\
\hline Enterobacter aerogenes & - & $7(0.58)$ & - & - \\
\hline Klebsiella spp. & - & $3(0.25)$ & $7(0.58)$ & $10(0.33)$ \\
\hline Escherichia coli & - & $4(0.22)$ & $10(0.83)$ & $17(0.57)$ \\
\hline Proteus vulgaris & - & - & $32(0.59)$ & $18(1)$ \\
\hline
\end{tabular}

\subsection{The handling and hygiene practices of Obushera processors and vendors in Mbarara City}

The handling and hygiene practices of locally processed sorghum/millet beverages (Obushera) determined (Table 6 ) revealed that most processors ( $82 \%$ ) observed used plastic containers as a primary vessel for preparing sorghum/millet Obushera. Using plastic containers in making different Obushera presents a microbial risk, especially due to cross-contamination. Although regarded cheap and user friendly, using plastic containers in making different Obushera presents a microbial and other health risks, especially when one plastic container is used in preparing different beverages. Using plastic is not recommendable as the surface easily scratched normal cleaning systems, making it hard to clean and providing a hiding space for microbes. Also, plastic containers are unsuitable for processing Obushera as they are sensitive to heat and long-term exposure to cleaning detergents. Worse still, the use of reusable plastic bottles in packaging Obushera make this more alarming, considering that most processors reported collecting the bottles from dumpsters and along the roadsides with only $11.8 \%$ using new plastic packaging material. In other studies, Mwale (2014) found that $64.7 \%$ of Munkoyo and Chibwantu (a locally fermented cereal-based beverage in Zambia) processors used recyclable plastic bottles such as reusable juice and water bottles in packaging the drink. The consumption of Obushera packaged in unhygienic containers creates a potential hazard to public health as it can lead to diarrheal disease and 
communicable diseases, including cholera and typhoid as indicated by the presence of E. coli and Proteus vulgaris as also documented by Byakika et al.(2019).

Approximately (64.3\%) of processors used tapped water in making sorghum/millet Obushera (Table 6). The microbial safety of tap water used by processors is not guaranteed since previous studies have found heavy microbial contamination, especially by coliform bacteria in un-boiled tap water in Uganda (Alarakol et al., 2017; Apecu et al., 2019). Our finding parallels Byakika et al.(2019), who reported that $89.4 \%$ of Obushera processors in Kampala, Uganda, used tap water. We observed that the containers used for the distribution and storage of tap water were dirty buckets and jerrycans; hence, the storage of clean water in dirty vessels will still lead to the re-contamination of water. Processors who use un-boiled water from open unclean buckets and jerrycans to process Obushera risk consumers since microbes such as coliforms could persist in the beverage, which can easily cause diarrheal disease outbreaks.

About $50 \%$ of bushera processors reported not boiling water for processing the drink exposing consumers to many microbial contaminants including bacteria such as E.coli, Vibrio cholera, Salmonella spp., protozoans such as Giardia, and viruses such as viruses adenoviruses, among others that are usually inactivated during water treatment processes. However, some of them still find their way into the water system through re-contamination of the distribution channels. Therefore, the presence of these bacteria in Obushera could be due to the use of unboiled water and unclean water holding vessels used in distributing and storing water for Obushera. Various researchers have attributed the presence of pathogenic bacteria in street-vended beverages to unboiled water used in the production processing of the drinks (Isoni Auad et al., 2019; Mohd Nawawee et al., 2019; Nemo et al., 2017). Therefore, water could be a possible determinant of beverage microbial contamination. Therefore, this study recommends processors to use water from protected wells and springs, treated water preferably chlorinated water and treated tap water directly connected to processing and vending sites. Majority of processors recycled water used for cleaning utensils possibly due to cost of purchasing water in a bid to reducing water bills and maximize profits. This scenario has also been reported by Chukuezi (2010) in Nigeria and Kampala city by Muyanja et al.(2011) which still point to the dire need of availability of safe and affordable water sources in African cities.

An observation of the production environment of Obushera in Mbarara city revealed that nearly all the sites lacked basic amenities (Table 6) that conform to good manufacturing practices (GMP) that entail practices that minimize microbial contamination of food such as adequate maintenance of production premises, control of litter and proper drainage, enough toilet facilities which does not open directly to processing area, and adequate hand washing facilities in both toilets and processing areas which is operated by foot or electronically, hand sanitization detergents or soap at hand washing areas, and paper towels to clean hands (EAST AFRICAN STANDARD: Hygiene in the Food and Drink Manufacturing Industry - Code of Practice, n.d.). Most processors of Obushera in Mbarara city did not meet most of the GMP. About $67 \%$ had garbage bins near the processing booths with overflowing garbage, encouraging processors and vendors to dispose of litter in surrounding stalls. $89 \%$ of processing sites had the presence of various vectors such as house flies, cockroaches, and rats in their vicinities. The garbage 
booths attract these vectors that can act as intermediaries for transmitting pathogenic microbes to humans. Flies are known predictors of E.coli contamination in food (Birgen et al., 2020), which can cause serious diarrheal diseases to humans, thus, the presence of flies in processing and vending sites is alarming to consumers of Obushera as they are at risk of diarrheal diseases. Similar results what was reported by Kitagwa et al. (2012) in Eldoret, Kenya. To make it worse, $75 \%$ of the processors lacked toilet facilities in their surroundings, and $79 \%$ lacked a handwashing facility hence a high possibility that most processors could not wash their hands after visiting toilets which raises serious food safety and sanitary concerns. Processors could have introduced the bacterial contaminants belonging to proteobacteria such as $E$. coli into the beverages during handling, especially after visiting toilets. The absence of adequate toilet facilities increases the chance of open defecation leading up to an unhealthy environment contaminated by human wastes. Erosion of such human wastes during rainy season increasing the chances of infection, especially by bacteria such as Vibrio cholerae.

Hill et al.(2016) observed that street vendors in South Africa operated in a hygienic environment with basic amenities and consequently produce relatively safer food with low microbial counts. A recommendation for the Mbarara city council to provide adequate toilet facilities, adequate drainage and water supply to Obushera processors to improve food safety and guarantee public health. An estimated $61 \%$ of the processors operated an open-air environment, a percentage that is higher than similar studies reported by Birgen et al.(2020) in Kenya and Chukuezi (2010)in Nigeria. This allows dust particles to find their way into the beverage, causing contamination from airborne contaminants like fungi such as Aspergillus spp., Penicillium spp. and bacteria including Staphylococcus spp. and Lactococcus spp. (Clauß, 2015).

Processors of Obushera in Mbarara did not undergo health inspection, which concurs with the findings of Byakika et al.(2019) making it a national problem. Djéni et al.(2014) reported a similar finding in which they established insufficient health inspection of a fermented cassava drink (attieke) in Côte d'Ivoire. Our results also corroborate the findings of (Badrie et al., 2004; Birgen et al., 2020) in Kenya, and TrinidadTobago, respectively. Previous researchers have noted lack of trust in food safety laws, lack of motivation in dealing with food safety laws and lack of adequate knowledge on food safety legislation as some of the barriers to enforcement of food safety guidelines by relevant city authorities (Yapp \& Fairman, 2006). It is therefore hoped that this study will provide an eye opener that food safety guidelines are needed in the recently established cities such as Mbarara for healthy city populations.

Ignorance and lack of guidelines' enforcement was still evidenced by the fact that $96.4 \%$ of processors did not use any protective outer garment and handled money during the processing and handling of Obushera. Lack of outer protective garments was also found in Nigeria although not to the same extent where Chukuezi (2010) reported that $42.86 \%$ of street-vendors in Nigeria did not wear aprons while $52.38 \%$ did not cover their hair during food processing and handling. Birgen et al. (2020) who isolated similar microbes with the present study and who noted that that street merchants in Nairobi, Kenya handled food at the same time money with bare hands, hence, cross-contaminating the food. This trend can lead to cross-contamination from humans to food, leading to the introduction of harmful pathogens 
to Obushera. Food processors and handlers are the largest single sources of microbial contamination of food. The sources of antibiotic resistant coagulase-positive Staphylococci, which was isolated by this study could be from the bare hands of processors and vendors, as also noted by Nguyen et al.(2018). Thus, it is recommended that food handlers should avoid handling money and food simultaneously to avoid cross-contamination. According to FAO et al. (1999) revised guidelines for street foods in Africa, clean forks or gloves should be used in handling of food.

Table 6

Observed handling and hygiene practice of Obushera in Mbarara city

\begin{tabular}{|lll|}
\hline Handling and Hygiene practices & \multicolumn{2}{l|}{$\begin{array}{l}\text { Percentage (\%) of the respondents } \\
\text { and number (n) }\end{array}$} \\
\cline { 2 - 3 } & correct & wrong \\
\hline Using metallic container for preparing Obushera & $14.2(4)$ & $85.7(24)$ \\
\hline Use of tapped water in preparing the beverages & $64.3(18)$ & $35.7(10)$ \\
\hline Use of Boiled water for preparing Obushera & $50(14)$ & $50(14)$ \\
\hline Regular changing of water for washing utensils & $0(0)$ & $100(28)$ \\
\hline Ventilated area of operation & $60.7(17)$ & $39.3(11)$ \\
\hline Presence of uncovered garbage near production sites & $32.1(9)$ & $67.9(19)$ \\
\hline Presence of vectors & $10.7(3)$ & $89.3(25)$ \\
\hline Handwashing during handling of Obushera & $10.7(3)$ & $89.3(25)$ \\
\hline $\begin{array}{l}\text { Use of protective gears such as aprons and gloves during } \\
\text { handling of Obushera }\end{array}$ & $3.6(1)$ & $96.4(27)$ \\
\hline Use of sanitized packaging material & $10.7(3)$ & $89.3(25)$ \\
\hline Storage of Obushera for not more than 3 days & $71.4(20)$ & $28.6(8)$ \\
\hline Health Inspection of Processors & $0.0(0)$ & $100(28)$ \\
\hline
\end{tabular}

\subsection{Conclusion}

The occurrence of microbes such as Escherichia coli, Staphylococcisp. and members of Enterobacter indicates that consumers of Obushera are prone to infection and diseases like food poisoning and diarrheal diseases. Majority of Obushera sampled and analyzed in this study did not meet the legal microbial regulatory standard for bacteria and fungi. The presence of unacceptable levels of fungi and bacteria suggests hygiene and handling practices needs to be improved in order to guarantee safety upon 
consumption of the beverages. The processors prepared and served the Obushera cold and this couple with poor preparation environment contributed to high microbial contamination revealed by this study. The results from this study emphasizes a pressing need for stringent monitoring and enforcement of regulations regarding Obushera by Uganda's ministry of Health, as majority of consumers are relying on this beverage. Storage time, $\mathrm{pH}$, amino acid concentration, reducing sugars and temperature conditions affected microbial growth and consequently contamination of Obushera beverages. The size of initial inoculum also affected persistence of microbes and contamination of Obushera. Therefore, concerted efforts are required in reducing inoculum size and this can be achieved by minimizing microbial contamination at the sources. Further, the isolated bacterial strains from Obushera were resistant to essential commonly used antibiotics which indicates a serious public health concern, therefore antibiotic use should be based on prescription to avert spread of antibiotic resistant bacteria in the population.

\section{Declarations}

\section{Acknowledgments}

The authors express gratitude to the staff of the microbiology laboratory at the faulty of Medicine, Mbarara University Regional Referral Hospital. Also, we acknowledge Obushera processors within Mbarara City, Uganda, for their cooperation in sample collection.

\section{Author's contribution}

All authors who contributed to this manuscript are listed. The authors reviewed and approved the final manuscript.

\section{Funding}

Not applicable

\section{Availability of data and materials}

All data are available within this article, but additional data can be requested through the corresponding author.

\section{Competing interests}

The authors declare no competing interests.

\section{Author's information}

${ }^{1}$ Department of Biology, Mbarara University of Science and Technology, P. O. Box 1410 Mbarara, Uganda

${ }^{2}$ Pharm-Biotechnology and Traditional Medicine Centre, Mbarara University of Science and Technology P. O. Box 1410 Mbarara, Uganda 


\section{References}

1. Administration, U. S. F. and D. (2013). Evaluation and Definition of Potentially Hazardous Foods in Factors that Influence Microbial Growth. US Food and Drug Administration, USA.

2. Akindele, A. A., Adewuyi, I. K., Adefioye, O. A., Adedokun, S. A., \& Olaolu, A. O. (2010). Antibiogram and beta-lactamase production of Staphylococcus aureus isolates from different human clinical specimens in a tertiary health institution in Ile-ife, Nigeria. American-Eurasian Journal of Scientific Research, 5(4), 230-233.

3. Alarakol, S. P., Nakavuma, J. L., Odong, P., \& Byarugaba, D. K. (2017). Evaluation of microbial quality of water in Kawempe Division, Kampala Surburb. East African Medical Journal, 94(12).

4. Albalasmeh, A. A., Berhe, A. A., \& Ghezzehei, T. A. (2013). A new method for rapid determination of carbohydrate and total carbon concentrations using UV spectrophotometry. Carbohydrate Polymers, 97(2), 253-261.

5. Alhaj, N., Mariana, N. S., Raha, A. R., \& Ishak, Z. (2007). Prevalence of antibiotic resistance among Escherichia coli from different sources in Malaysia. International Journal of Poultry Science, 6(4), 293-297.

6. Ali, S. Q., Zehra, A., Naqvi, B. S., Shah, S., \& Bushra, R. (2010). Resistance pattern of ciprofloxacin against different pathogens. Oman Medical Journal, 25(4), 294.

7. Apecu, R. O., Ampaire, L., Mulogo, E. M., Bagenda, F. N., Traore, A., \& Potgieter, N. (2019). Quality of water sources in Southwestern Uganda using the compartment bag test (CBT): a cross-sectional descriptive study. Journal of Water, Sanitation and Hygiene for Development, 9(4), 683-693.

8. Ayandele, A. A., Oladipo, E. K., Oyebisi, O., \& Kaka, M. O. (2020). Prevalence of multi-antibiotic resistant Escherichia coli and Klebsiella speci1. A.A. Ayandele, E.K. Oladipo, O. Oyebisi, and M.O. Kaka: "Prevalence of multi-antibiotic resistant Escherichia coli and Klebsiella species obtained from a tertiary medical ins. Qatar Medical Journal, 2020(1), 9.

9. Badrie, N., Joseph, A., \& Chen, A. (2004). An observational study of food safety practices by street vendors and microbiological quality of street-purchased hamburger beef patties in Trinidad, West Indies. Internet Journal of Food Safety, 3, 25-31.

10. Barrett, S. P., Savage, M. A., Rebec, M. P., Guyot, A., Andrews, N., \& Shrimpton, S. B. (1999). Antibiotic sensitivity of bacteria associated with community-acquired urinary tract infection in Britain. Journal of Antimicrobial Chemotherapy, 44(3), 359-365.

11. Ben, A. S., Ainsley, M. O., Aamir, M. F., Greg, M. P., Anna, M. L., Downes, F. P., \& Ito, K. (2013). Microbial food safety risk assessment. Compendium of Methods for the Microbiological Examination of Foods. In: Eds. Downes FP, Ito K, Eds. American Public Health Association, 1 Á369.

12. Birgen, B. J., Njue, L. G., \& Kaindi, D. M. (2020). Birgen_Determinants of Microbial Contamination of Street-Vended Chicken Products Sold in Nairobi County, Kenya.

13. Byakika, S., Mukisa, I. M., Byaruhanga, Y. B., Male, D., \& Muyanja, C. (2019). Influence of food safety knowledge, attitudes and practices of processors on microbiological quality of commercially 
produced traditional fermented cereal beverages, a case of Obushera in Kampala. Food Control, 100, 212-219.

14. Byakika, S., Muzira, I., Byenkya, Y., Male, D., \& Muyanja, C. (2019). In fl uence of food safety knowledge, attitudes and practices of processors on microbiological quality of commercially produced traditional fermented cereal beverages , a case of Obushera in Kampala. Food Control, 100(July 2018), 212-219. https://doi.org/10.1016/j.foodcont.2019.01.024

15. Chukuezi, C. O. (2010). Food safety and hyienic practices of street food vendors in Owerri, Nigeria. Studies in Sociology of Science, 1(1), 50-57.

16. Clauß, M. (2015). Particle size distribution of airborne microorganisms in the environment-a review. Landbauforsch Appl Agric Forestry Res, 65(2), 77-100.

17. Collee, J. G., Mackie, T. J., \& McCartney, J. E. (1996). Mackie \& McCartney practical medical microbiology. Harcourt Health Sciences.

18. Cowan, S. T. (1973). Characters of Gram-negative Bacteria. Manual for the Identification of Medical Bacteria., 61.

19. de Normalisation, O. I. (2003). Microbiologie des aliments. Methode horizontale pour le denombrement des bacteries sulfito-reductrices se developpant en conditions anaerobies.

20. Djéni, T. N., Kouamé, A. K., Traoré, Y., Nevry, R. K., \& Marcellin, K. D. (2014). Assessment of knowledge, attitudes and practices of food handlers in Attieke production units in relation to food hygiene and safety in Côte d'Ivoire in 2012. Food and Nutrition Sciences, 2014.

21. EAST AFRICAN STANDARD: Hygiene in the food and drink manufacturing industry - Code of practice. (n.d.). Retrieved February 1, 2022, from

https://law.resource.org/pub/eac/ibr/eas.39.2001.html

22. Elmahmood, A. M., \& Doughari, J. H. (2007). Microbial quality assessment of kunun-zaki beverage sold in Girei town of Adamawa State, Nigeria. African Journal of Food Science, 1(1), 11-15.

23. FAO, H. N. F., Odunfa, S. A., Lee, C. H., Quintero-Ramírez, R., Lorence-Quiñones, A., \& Wacher-Radarte, C. (1999). Agricultural services bulletin no 138.

24. Gitahi, M. G. (2012). Microbial quality, strain distribution and enterotoxigenicity of selected food borne pathogens in relation to the hygienic practices in Industrial area, Nairobi, Kenya. University of Nairobi, Kenya.

25. Goswami, N. N., Trivedi, H. R., Goswami, A. P. P., Patel, T. K., \& Tripathi, C. B. (2011). Antibiotic sensitivity profile of bacterial pathogens in postoperative wound infections at a tertiary care hospital in Gujarat, India. Journal of Pharmacology \& Pharmacotherapeutics, 2(3), 158.

26. Grace, D. (2015). Food safety in low and middle income countries. International Journal of Environmental Research and Public Health, 12(9), 10490-10507.

27. Green III, F., Clausen, C. A., \& Highley, T. L. (1989). Adaptation of the Nelson-Somogyi reducing-sugar assay to a microassay using microtiter plates. Analytical Biochemistry, 182(2), 197-199. 
28. Gufe, C., Canaan Hodobo, T., Mbonjani, B., Majonga, O., Marumure, J., Musari, S., Jongi, G., Makaya, P. V., \& Machakwa, J. (2019). Antimicrobial profiling of bacteria isolated from fish sold at informal market in Mufakose, Zimbabwe. International Journal of Microbiology, 2019.

29. Hill, J., Mchiza, Z., Fourie, J., Puoane, T., \& Steyn, N. (2016). Consumption patterns of street food consumers in Cape Town. Journal of Family Ecology and Consumer Sciences= Tydskrif Vir Gesinsekologie En Verbruikerswetenskappe, 2016(sed-2), 25-35.

30. Holt, J. G., Krieg, N. R., \& Sneath, P. H. A. (2013). Bergey's manual of determinative bacterology.

31. Isoni Auad, L., Cortez Ginani, V., Stedefeldt, E., Yoshio Nakano, E., Costa Santos Nunes, A., \& Puppin Zandonadi, R. (2019). Food safety knowledge, attitudes, and practices of brazilian food truck food handlers. Nutrients, 11(8), 1784.

32. Jay, J. M. (2000). Modern food microbiology. 6th edit. An ASPEN Publication. Gaithersburg, Maryland.

33. Kelly, A., Osburn, B., \& Salman, M. (2014). Veterinary medicine's increasing role in global health. The Lancet Global Health, 2(7), e379-e380.

34. Kitagwa, W. G., Bekker, J. L., \& Onyango, R. O. (2012). An assessment of knowledge, attitudes and practices of food handlers in food kiosks in relation to food hygiene in Eldoret, Kenya. International Journal of Current Research, 4(4), 127-138.

35. Kramer, A., Schwebke, I., \& Kampf, G. (2006). How long do nosocomial pathogens persist on inanimate surfaces? A systematic review. BMC Infectious Diseases, 6(1), 1-8.

36. Le Hello, S., Hendriksen, R. S., Doublet, B., Fisher, I., Nielsen, E. M., Whichard, J. M., Bouchrif, B., Fashae, K., Granier, S. A., \& Jourdan-Da Silva, N. (2011). International spread of an epidemic population of Salmonella enterica serotype Kentucky ST198 resistant to ciprofloxacin. Journal of Infectious Diseases, 204(5), 675-684.

37. Malav, O. P., Sharma, B. D., Talukder, S., Kumar, R. R., \& Mendiratta, S. K. (2013). Shelf life evaluation of restructured chicken meat blocks extended with sorghum flour and potato at refrigerated storage $\left(4 \pm 1^{\circ} \mathrm{C}\right)$. International Food Research Journal, $20(1)$.

38. Mandal, M. D., \& Mandal, S. (2011). Honey: its medicinal property and antibacterial activity. Asian Pacific Journal of Tropical Biomedicine, 1(2), 154-160.

39. Masaphy, S. (2013). Development of Media for Growth and Enumeration of Fungi from Water. In Laboratory Protocols in Fungal Biology (pp. 201-209). Springer.

40. Mendez-Vilas, A. (2015). Multidisciplinary Approaches for Studying and Combating Microbial Pathogens. Universal-Publishers.

41. Mishra, M. P., Debata, N. K., \& Padhy, R. N. (2013). Surveillance of multidrug resistant uropathogenic bacteria in hospitalized patients in Indian. Asian Pacific Journal of Tropical Biomedicine, 3(4), 315324.

42. Mitscherlich, E., \& Marth, E. H. (2012). Microbial survival in the environment: bacteria and rickettsiae important in human and animal health. Springer Science \& Business Media. 
43. Mohd Nawawee, N. S., Abu Bakar, N. F., \& Zulfakar, S. S. (2019). Microbiological safety of streetvended beverages in Chow Kit, Kuala Lumpur. International Journal of Environmental Research and Public Health, 16(22), 4463.

44. Mukisa, I. M., Porcellato, D., Byaruhanga, Y. B., Muyanja, C. M. B. K., Rudi, K., Langsrud, T., \& Narvhus, J. A. (2012). The dominant microbial community associated with fermentation of Obushera (sorghum and millet beverages) determined by culture-dependent and culture-independent methods. International Journal of Food Microbiology. https://doi.org/10.1016/j.jifoodmicro.2012.09.023

45. Muleta, D., \& Ashenafi, M. (2001). Bacteriological profile and holding temperatures of street-vended foods from Addis Ababa. International Journal of Environmental Health Research, 11(1), 95-105.

46. Muyanja, C., Nayiga, L., Brenda, N., \& Nasinyama, G. (2011). Practices, knowledge and risk factors of street food vendors in Uganda. Food Control, 22(10), 1551-1558.

47. Mwale, M. M. (2014). Microbiological quality and safety of the Zambian fermented cereal beverage: Chibwantu. University of the Free State.

48. Mwambete, K. D., \& Peter, A. (2011). Microbiological Quality of Juice Beverages Available in Dar es Salaam and Resistance Profiles of Microbial Contaminants. East and Central African Journal of Pharmaceutical Sciences, 14(3).

49. Nakai, S., \& Le, A. C. (1970). Spectrophotometric determination of protein and fat in milk simultaneously. Journal of Dairy Science, 53(3), 276-278.

50. Namugambe, J. S., Delamou, A., Moses, F., Ali, E., Hermans, V., Takarinda, K., Thekkur, P., Nanyonga, S. M., Koroma, Z., \& Mwoga, J. N. (2021). National Antimicrobial Consumption: Analysis of Central Warehouses Supplies to In-Patient Care Health Facilities from 2017 to 2019 in Uganda. Tropical Medicine and Infectious Disease, 6(2), 83.

51. Neely, A. N. (2000). A survey of gram-negative bacteria survival on hospital fabrics and plastics. The Journal of Burn Care \& Rehabilitation, 21(6), 523-527.

52. Nemo, R., Bacha, K., \& Ketema, T. (2017). Microbiological quality and safety of some-street-vended foods in Jimma Town, Southwestern Ethiopia. African Journal of Microbiology Research, 11(14), 574-585.

53. Nguyen, A. T. Le, Tran, B. X., Le, H. T., Le, X. T. T., Do, K. N., Do, H. T., Vu, G. T., Nguyen, L. H., Latkin, C. A., \& Ho, C. S. H. (2018). Customers' knowledge, attitude, and practices towards food hygiene and safety standards of handlers in food facilities in Hanoi, Vietnam. International Journal of Environmental Research and Public Health, 15(10), 2101.

54. Odeyemi, O. A., \& Sani, N. A. (2016). Antibiotic resistance and burden of foodborne diseases in developing countries. Future Science.

55. Olatoye, I. O. (2010). The incidence and antibiotics susceptibility of Escherichia coli 0157: H7 from beef in Ibadan Municipal, Nigeria. African Journal of Biotechnology, 9(8).

56. Organization, W. H. (2014). Preventing diarrhoea through better water, sanitation and hygiene: exposures and impacts in low-and middle-income countries. World Health Organization. 
57. Organization, W. H. (2015). WHO estimates of the global burden of foodborne diseases: foodborne disease burden epidemiology reference group 2007-2015. World Health Organization.

58. Raosoft, I. (2004). Sample size calculator. Available from: WW Raosoft Com/Samplesize.

59. Raybaudi-Massilia, R. M., Mosqueda-Melgar, J., Soliva-Fortuny, R., \& Martín-Belloso, O. (2009). Control of pathogenic and spoilage microorganisms in fresh-cut fruits and fruit juices by traditional and alternative natural antimicrobials. Comprehensive Reviews in Food Science and Food Safety, $8(3), 157-180$.

60. Richardson, M. D., \& Rautemaa-Richardson, R. (2020). Biotic environments supporting the persistence of clinically relevant Mucormycetes. Journal of Fungi, 6(1), 4.

61. Shitandi, A., \& Sternesjö, Å. S. E. (2001). Detection of antimicrobial drug residues in Kenyan milk. Journal of Food Safety, 21(4), 205-214.

62. Smith, S. M. (2013). Determining sample size. Retrieved February, 23, 2017.

63. Stankovic, I. (2015). Codex Alimentarius. Encyclopedia of Food and Health, 191-196. https://doi.org/10.1016/B978-0-12-384947-2.00180-X

64. Thenmozhi, S., Rajeswari, P., Kumar, B. T. S., Saipriyanga, V., \& Kalpana, M. (2014). Multi-drug resistant patterns of biofilm forming Aeromonas hydrophila from urine samples. International Journal of Pharmaceutical Sciences and Research, 5(7), 2908.

65. Vieira-Dalodé, G., Jespersen, L., Hounhouigan, J., Moller, P. L., Nago, C. M., \& Jakobsen, M. (2007). Lactic acid bacteria and yeasts associated with gowé production from sorghum in Bénin. Journal of Applied Microbiology, 103(2), 342-349.

66. Von Holy, A., \& Makhoane, F. M. (2006). Improving street food vending in South Africa: Achievements and lessons learned. International Journal of Food Microbiology, 111(2), 89-92.

67. Wagenvoort, J. H. T., Sluijsmans, W., \& Penders, R. J. R. (2000). Better environmental survival of outbreak vs. sporadic MRSA isolates. Journal of Hospital Infection, 45(3), 231-234.

68. Wayne, A. (2010). Clinical and Laboratory Standards Institute; CLSI. 2011. Performance standards for antimicrobial susceptibility testing. 20th Informational Supplement. CLSI Document.

69. Yapp, C., \& Fairman, R. (2006). Factors affecting food safety compliance within small and mediumsized enterprises: implications for regulatory and enforcement strategies. Food Control, 17(1), 4251.

\section{Figures}




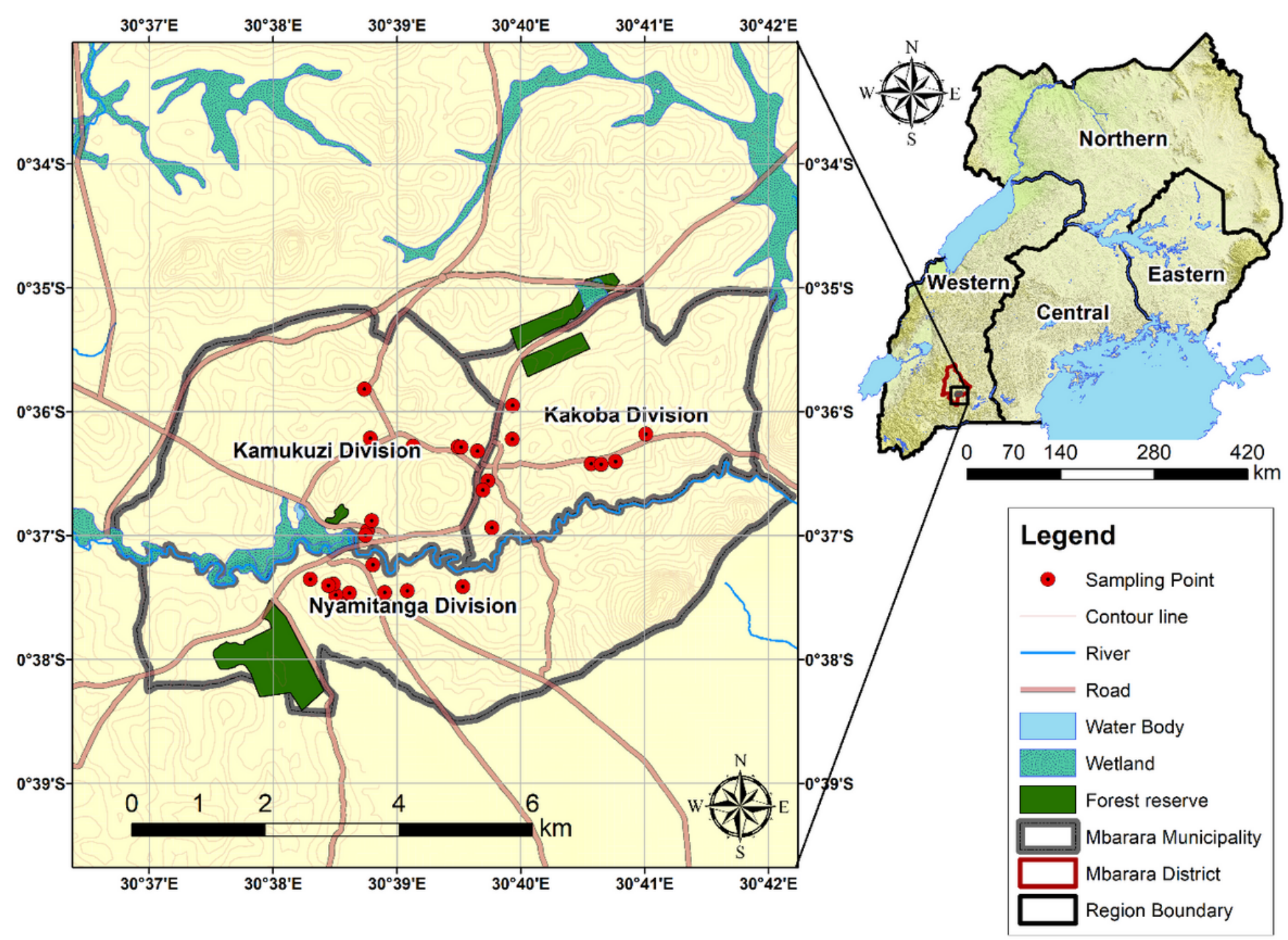

Figure 1

A map of Uganda, extended is a map of Mbarara district showing sampling sites in Mbarara City. 

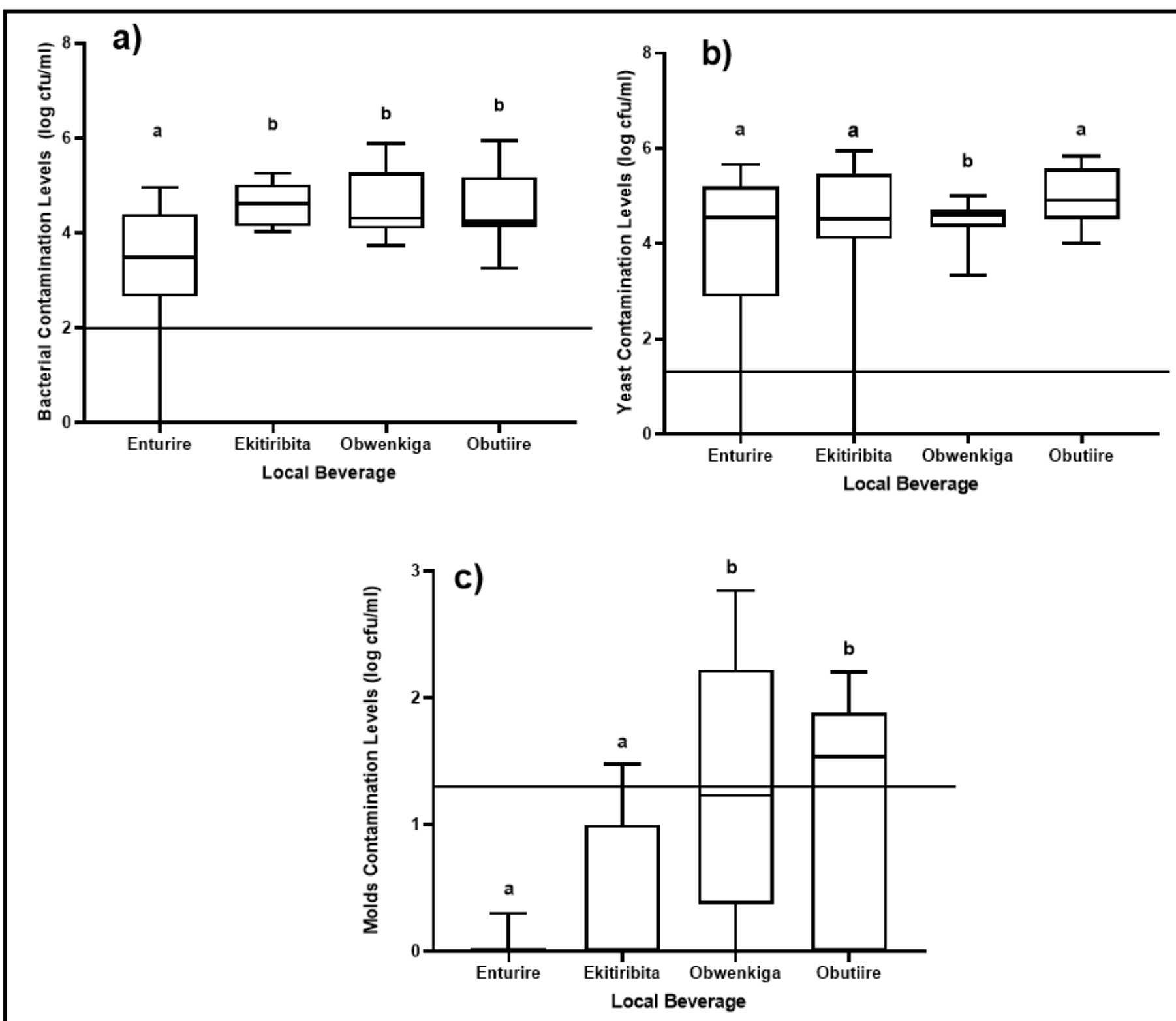

Figure 2

a-c): Variation in microbial contamination of "obushera" local beverage sold in Mbarara City, Uganda: a) Total viable counts (log cfu/ml), b) Yeast contamination (log cfu/ml), c) Mold contamination (log $\mathrm{cfu} / \mathrm{ml}$ ). Box and whiskers with different lowercase letters indicate significant difference at $p<0.05$ based on Dunn's multiple comparison test, horizontal line (-) indicates allowable limits set by UNBS for microbial contamination. 
Persistence of microbes at $26^{\circ} \mathrm{C}$

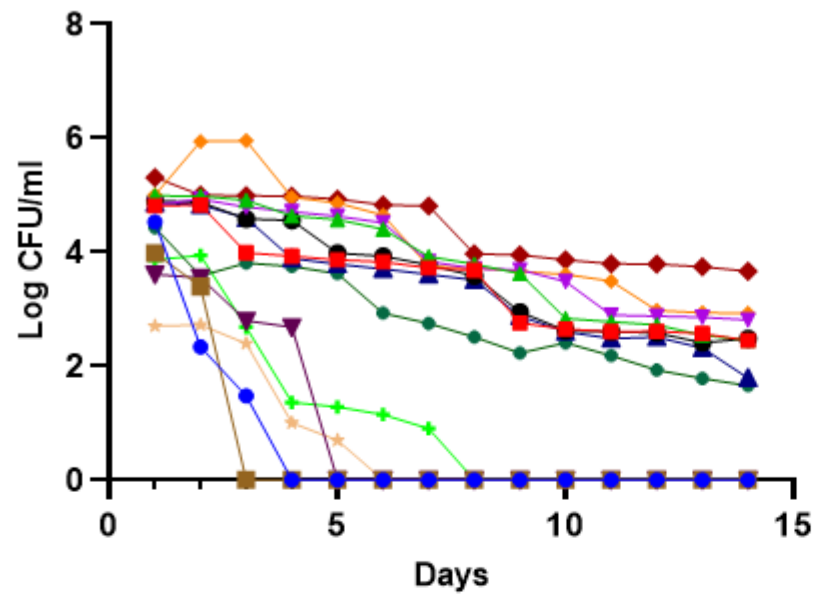

$\longrightarrow$ Providencia spp.

Coagulase-postive

- Staphylococcus sp. (non-aureus)

$\rightarrow$ E.cloacae

$\rightarrow$ E.aerogens

$\multimap$ E.coli

- Klebsiella spp.

- Proteus vulgaris

- - Streptococcus spp.

$\boldsymbol{\nabla}$ Pseudomonas spp.

$\downarrow$ S.cerevisiae

$\rightarrow$ Candida spp.

* Mucor spp.

+ Aspergillus niger

\section{Persistence of microbes at $4^{\circ} \mathrm{C}$}

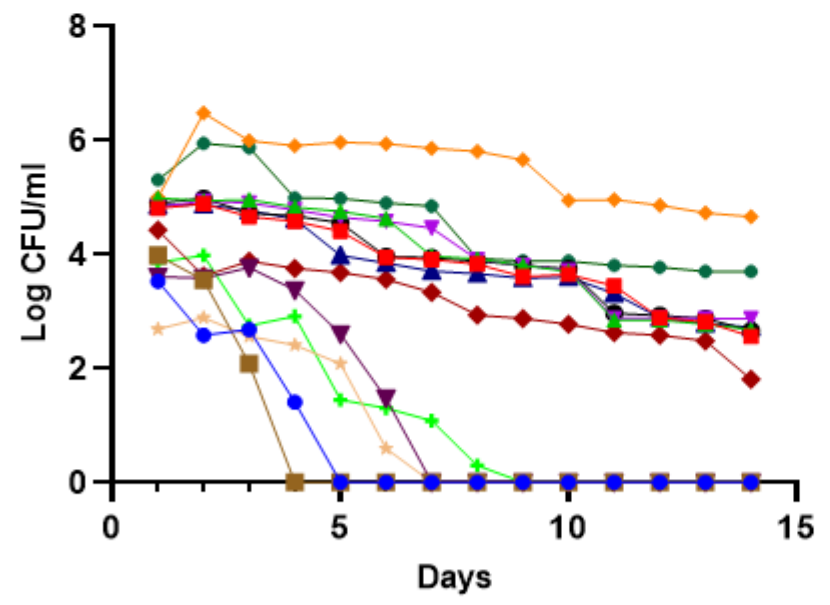

- Providencia spp.

Coagulase-postive

-- Staphylococcus sp. (non-aureus)

$\rightarrow$ E.cloacae

$\rightarrow$ E.aerogens

$\leftrightarrow$ E.coli

- Klebsiella spp.

- Proteus vulgaris

- - Streptococcus spp.

$\rightarrow$ Pseudomonas spp.

$\bullet$ S.cerevisiae

$\bullet \quad$ Candida spp.

* Mucor spp.

+ Aspergillus niger

\section{Figure 3}

Persistence of microbes under room temperature $\left(26^{\circ} \mathrm{C}\right)$ and refrigerated temperature $\left(4^{\circ} \mathrm{C}\right)$ with storage time of 14 days 